\title{
10-Years Studies of the Soil Physical Condition after One-Time Biochar Application
}

\author{
Jacek Pranagal ${ }^{1}$ (D) and Piotr Kraska ${ }^{2, *}$ (D) \\ 1 Institute of Soil Science, Environment Engineering and Management, University of Life Sciences, \\ Leszczyńskiego 7, 20-069 Lublin, Poland; jacek.pranagal@up.lublin.pl \\ 2 Department of Herbology and Plant Cultivation Techniques, University of Life Sciences in Lublin, \\ Akademicka 13, 20-950 Lublin, Poland \\ * Correspondence: piotr.kraska@up.lublin.pl; Tel.: +48-81-445-67-78
}

Received: 17 September 2020; Accepted: 13 October 2020; Published: 16 October 2020

\begin{abstract}
The ten-year experiment on the soil physical properties of biochar-amended Podzol was studied. Biochar was applied to the soil in the following rates: treatment $\mathrm{BC} 10-10 \mathrm{Mg} \times \mathrm{ha}^{-1}$, treatment BC20-20 Mg $\times \mathrm{ha}^{-1}$, treatment BC30-30 Mg $\times \mathrm{ha}^{-1}$ and treatment BC0-Control (soil without the addition of biochar). Biochar was mixed the soil arable layer $(0-20 \mathrm{~cm})$. Soil samples were collected ten times, once a year-after harvest rye. They were taken from layers: $0-10 \mathrm{~cm}$ and $10-20 \mathrm{~cm}$, in six replicates, using $100 \mathrm{~cm}^{3}$ metal cylinders. The soil physical properties were determined: particle size distribution, particle density, bulk density, total porosity, air capacity and permeability (at $-15.5 \mathrm{kPa}$ ), water content at sampling, field water capacity (at $-15.5 \mathrm{kPa}$ ), available and unavailable water content, and the ratio of field water capacity and total porosity was calculated. It was found that biochar application causes changes in the soil physical condition. The soil density decreased, while the porosity, aeration and water retention increased; the ratio of field water capacity and total porosity was favorable. These changes cannot be considered as permanent. Most of the analyzed properties showed a durability of no more than 3-4 years. We found that biochar incorporation into soil is a good method for environmental management of waste biomass.
\end{abstract}

Keywords: Podzols; waste wheat straw; biochar; bulk density; total porosity; air capacity; air permeability; soil moisture; field water capacity; available water content

\section{Introduction}

The data on global soil resources show the continuous increase in the area of degraded soils [1-4]. Therefore, an important element in management of soils is to prevent their degradation. Taking preventive actions is considered to be a better approach than the subsequent implementation of soil remediation measures [5-9]. Soil is an irreplaceable element of the environment and it is subjected to the pressure of various degrading factors. Excessively compacted soils occur commonly. The studies by some authors, e.g., Jones [10], McQueen and Shepherd [11], Drewry et al. [12], Reynolds et al. [13,14], and Pranagal [15], indicate that high soil compaction may limit the growth of crop plants.

Soil is a complex medium that undergoes dynamic changes both in time and on its surface [16-20]. The properties of soil can be modified by incorporating diverse mineral and/or organic materials into it $[6,7,15,21-24]$. Waste materials originating from different industries, including agriculture, are used very frequently for this purpose. According to many authors, application of organic wastes to soil inhibits soil degradation, improves soil quality, and has a beneficial impact in the context of safe food. However, these authors also admit that most organic wastes decompose quickly and their next applications are required $[8,9,21,22,25]$. Management of waste by its application to soil allows two objectives to be achieved: (i) to dispose of waste, and (ii) to improve soil properties $[6,8,9,15,21,22,25-27]$. 
An interesting method for disposal of waste biomass is to convert it into biochar under pyrolysis conditions. The interest in application of biochar as an environmentally friendly material is growing. A number of environmental benefits arising from the use of biochar are mentioned, e.g.,: (i) soil remediation [7,8,15,28,29]; (ii) increased soil carbon sequestration [29-31]; (iii) enhanced soil productivity [27,30,31]; (iv) neutralization of soil acidity [32-34]; (v) wastewater treatment [35,36]; (vi) cleaning of air [30,37]; and (vii) reduction in greenhouse gas emissions $[27,30,32,38]$. The use of biochar is also considered to be an element of sustainable agricultural practice [27,30,31]. Biochar exhibits very good sorption properties and is also resistant to the action of chemicals and biochemical degradation $[27,30,39]$. Hence, the properties of biochar allow it to be used for soil phytostabilization [40,41].

An important aspect of biochar addition to soil is a change in its physical properties. The soil physical condition (e.g., compaction, air-water properties, distribution and openness of soil pores) plays an essential role in soil functioning. It determines conditions in which chemical reactions and biochemical and microbiological transformations take place as well as the availability of nutrients to plants $[8,9,23,24]$. Existing research regarding the effect of biochar application on soil physical properties has found that the addition of biochar most frequently resulted in: (i) reduced soil compaction-A decrease in bulk density and an increase in total porosity; (ii) an increase in available water content; and (iii) an increase in soil water-stable aggregates content [5,8,9,42-46].

The EU legal regulations [47] require: (i) disposal of waste at landfills to be avoided, and (ii) the amount of waste designated for recycling to increase. It is also an important fact that the amount of farmyard manure produced in Poland has decreased in recent years [48]. Such a situation forces us to seek other sources of organic fertilizers. Meeting the environmental safety requirements is also a condition for using waste for agricultural purposes $[6,30,49,50]$.

An example of environment-oriented measures is the presented study which combines two environmental objectives: (i) to reduce the amount of waste disposed of at landfills, and (ii) to improve soil properties. This study was conducted as a multi-year field experiment in which biochar produced from waste winter wheat straw was used. The biochar was applied to a sandy soil—Podzol (PZ) [51] -at rates of 10,20 , and $30 \mathrm{Mg} \times \mathrm{ha}^{-1}$, respectively. The aim of this research was to carry out 10-year measurements of changes in the soil physical condition resulting from one-time biochar application. The study results were used to verify a hypothesis that one-time biochar amendment contributes to an improvement in soil physical properties and that resultant changes in soil properties are persistent.

\section{Materials and Methods}

\subsection{Study Area, Field Experiment and Sampling}

This study was located in eastern Poland and was carried out at the Agricultural Experimental Farm in Bezek- $51^{\circ} 12^{\prime} \mathrm{N} ; 23^{\circ} 17^{\prime} \mathrm{E}$. The study area is situated in the transitional temperate cool climate (Dfb), with a substantial influence of continental climate (https://pl.climate-data.org/info/sources). In the analyzed period (2010-2019), the average annual precipitation was $541.4 \mathrm{~mm}$. The average temperature of the warmest month (July) over the fallow period was $+18.1^{\circ} \mathrm{C}$, whereas the temperature of the coldest month (January) was $-3.2{ }^{\circ} \mathrm{C}$. The length of the growing period in the study area in question, which most frequently starts in the second or third 10 days of March and usually lasts until the end of October, is 210-215 days on average.

A ten-year (2010-2019) study was conducted on the physical properties of Podzol [51] originating from glaciofluvial fine-grained loamy sand (LS). The particle size distribution [52] of the arable layer of this soil is presented in the paper Pranagal et al. [8]. Total organic carbon content $\mathrm{TOC}=5.3 \mathrm{~g} \times \mathrm{kg}^{-1} ; \mathrm{pH}_{\mathrm{KCl}}=4.9 ; \mathrm{CaCO}_{3}$ trace amounts. In the field experiment biochar produced from waste biomass - winter wheat straw-was used. It was produced through pyrolysis conducted at a 
very low oxygen level (1-2\%) and at a maximum combustion temperature of $650^{\circ} \mathrm{C}$. The characteristics of the biochar used in the research are presented in the paper Pranagal et al. [8].

The field experiment was set up in the second 10 days of August 2010 in a field where winter rye (Secale cereale L., cv. "Dańkowskie Diament") was grown in monoculture. Monoculture cropping of winter rye continued for another 10 years (2010-2019). The maintenance of monoculture was intended to facilitate interpretation of results of determinations of soil physical properties. In this way, additional factors were avoided, which would have affected the soil physical condition, e.g., different agronomic practices and/or the effects of the root systems of crop plants. The experiment was set up in a randomized block design in three replicates. The area of each single plot was $18 \mathrm{~m}^{2}$. The spacing between plots fertilized with the different rates of biochar was $2 \mathrm{~m}$. The biochar was applied according to the following experimental design: treatment BC10-10 Mg $\times \mathrm{ha}^{-1}$; treatment $\mathrm{BC} 20-20 \mathrm{Mg} \times \mathrm{ha}^{-1}$; and treatment $\mathrm{BC} 30-30 \mathrm{Mg} \times \mathrm{ha}^{-1}$. No biochar was applied to the soil in one of the treatments and this was the control treatment (BC0). The biochar was initially spread over the soil surface, and subsequently ploughing was done at a depth of about $20 \mathrm{~cm}$ in order to mix it with the soil. Then, the soil surface was leveled with a power harrow. In the third 10 days of September, winter rye was sown using a cultivating seed drill. Winter rye was sown every year in the third 10-day period of September. Mineral fertilizers were applied every year of the experiment at the following rates: $70 \mathrm{~kg} \mathrm{ha}^{-1} \mathrm{~N}$ (ammonium nitrate), $26 \mathrm{~kg} \mathrm{ha}^{-1} \mathrm{P}$ (triple superphosphate), $66 \mathrm{~kg} \mathrm{ha}^{-1} \mathrm{~K}$ (muriate of potash, $\mathrm{KCl}$ ). Phosphorus and potassium fertilizers as well as $20 \mathrm{~kg} \mathrm{ha}^{-1} \mathrm{~N}$ were applied before sowing. In spring, the remaining portion of the nitrogen $(\mathrm{N})$ rate was applied before plant growth began $\left(30 \mathrm{~kg} \mathrm{ha}^{-1}\right)$ and at the stem elongation stage $\left(20 \mathrm{~kg} \mathrm{ha}^{-1}\right)$.

Undisturbed soil samples were collected once during every growing season-after harvest of rye in the first 10 days of August (sampling dates: I, II, III, ... IX). In order to determine the initial condition of the soil, samples were taken before biochar application—sampling date 0 (2010). Soil samples were collected from the layers of $0-10 \mathrm{~cm}$ and $10-20 \mathrm{~cm}$ to $100 \mathrm{~cm}^{3}$ metal cylinders in six replicates.

\subsection{Analyses}

Physical soil properties, such as particle size distribution (PSD), particle density (PD), bulk density (BD), total porosity (TP), air capacity (at $-15.5 \mathrm{kPa}$ ) (FAC), air permeability (at $-15.5 \mathrm{kPa}$ ) (FAP), water content at sampling (SM), field water capacity (FC), available water content (AWC), unavailable water content-permanent wilting point (UWC) and FC/TP ratio were studied. Soil water retention curve was determined with the use of a pressure plate apparatus (Soil-moisture Equipment Corp., Santa Barbara, California, USA). The level of field soil saturation with water was calculated for soil moisture level at a potential value of $-15.5 \mathrm{kPa}$ and permanent wilting point (UWC) of $-1550.0 \mathrm{kPa}$. The content of organic carbon (TOC) was measured with the use of a Shimadzu TOC-VCSH analyzer with an SSM-5000A adapter for solid sample combustion.

The soil physical properties were determined according to the following procedures:

- soil texture-particle size distributions (PSD)—with Casagrande method modified by Prószyński [53],

- particle density (PD) - with the pycnometric method [54] $\left(\mathrm{Mg} \times \mathrm{m}^{-3}\right)$,

- bulk density (BD) - with the gravimetric method, from the ratio of the mass of soil dried at $105^{\circ} \mathrm{C}$ to the initial soil volume of $100 \mathrm{~cm}^{3}$ [55] $\left(\mathrm{Mg} \times \mathrm{m}^{-3}\right)$,

- total porosity (TP) was calculated from the results of particle density (PD) and bulk density (BD), $\mathrm{TP}=1-\mathrm{BD} / \mathrm{PD}[56]\left(\mathrm{m}^{3} \times \mathrm{m}^{-3}\right)$,

- $\quad$ air capacity at the potential of $-15.5 \mathrm{kPa}(\mathrm{FAC})$ was derived from the results of total porosity (TP) and field water capacity (FC) $(-15.5 \mathrm{kPa}), \mathrm{FAC}=\mathrm{TP}-\mathrm{FC}[56]\left(\mathrm{m}^{3} \times \mathrm{m}^{-3}\right)$,

- $\quad$ air permeability at the potential of $-15.5 \mathrm{kPa}(\mathrm{FAP})$ was measured using an apparatus for the measurement of permeability of molding sand, LPiR-2e [7-9]. The measurements were conducted at vertical (upward) airflow through the soil sample. The pressure head in the measurement 
chamber was $0.981 \mathrm{kPa}\left(100 \mathrm{~mm} \mathrm{H}_{2} \mathrm{O}\right)$, and the ambient temperature was stabilized $\left(20 \pm 1.0^{\circ} \mathrm{C}\right)$. The relative air humidity was $40 \pm 5 \%$. The dynamic air viscosity $\left(10^{-8} \times \mathrm{m}^{2} \times \mathrm{Pa}^{-1} \times \mathrm{s}^{-1}\right)$ was not taken into account in the measurement results. The apparatus was produced by MULTISERW-Morek (Poland),

- water content at sampling (SM) was calculated from the ratio of the mass of water contained in the soil during the sampling to the dry matter of soil dried at $105^{\circ} \mathrm{C}$ [57] $\left(\mathrm{kg} \times \mathrm{kg}^{-1}\right)$,

- field water capacity (FC) was calculated from the ratio of the volume of water contained in the soil at the potential of $-15.5 \mathrm{kPa}$ to the soil volume $[58,59]\left(\mathrm{m}^{3} \times \mathrm{m}^{-3}\right)$,

- available water content (AWC) was obtained from FC (-15.5 kPa) and unavailable water content $(-1550.0 \mathrm{kPa})$ - permanent wilting point (UWC), AWC $=$ FC-UWC $[59,60]\left(\mathrm{m}^{3} \times \mathrm{m}^{-3}\right)$,

- unavailable water content (UWC) was calculated from the ratio of the volume of water contained in the soil at the potential of $-1550.0 \mathrm{kPa}$ to the soil volume $[58,59]\left(\mathrm{m}^{3} \times \mathrm{m}^{-3}\right)$.

Air-water relations of the soil were analyzed by determining the values of FC/TP ratio $[14,60,61]$.

\subsection{Statistical Analysis}

The results were statistically evaluated with analysis of variance (ANOVA). All pairs of means between treatments were compared with the Tukey's test and the lowest significant difference test (LSD). The analysis (two-way ANOVA-biochar application rate $(\mathrm{BC} 0, \mathrm{BC} 10, \mathrm{BC} 20, \mathrm{BC} 30) \times$ soil layer and one-way ANOVA-soil from treatments $\mathrm{BC}, \mathrm{BC} 10, \mathrm{BC} 20, \mathrm{BC} 30$ and sampling dates 0-IX-Table 1) was performed for the results concerning the soil from the layer $0-10 \mathrm{~cm}, 10-20 \mathrm{~cm}$ (Table 2) and 0-20 cm (Table 3). In that manner mean values for each soil property under analysis were compared. The statistical evaluations (ANOVA-LSD) were conducted assuming the significance level of $\alpha=0.05$. Statistica 11 by Statsoft and ARSTAT by University of Life Sciences in Lublin were used to statistical analyses.

\section{Results and Discussion}

\subsection{Soil Texture (PSD) and Density (PD and BD)}

As a basic characteristic, soil texture (PSD) is considered to be very stable. Significant changes in soil particle size distribution occur very rarely. The studied soil was also characterized by stable PSD. The biochar incorporated into it at different rates (BC10, $\mathrm{BC} 20$, and $\mathrm{BC} 30)$ did not cause any changes in soil texture. In the case of application of the higher biochar rates (BC20 and BC30), only minor changes, of about $\pm 0.5 \%$, in the content of the silt and clay fraction were recorded. Throughout the entire measurement period (2010-2019), the studied soil was classified as loamy sand (SL). As shown in the studies by Blott and Pye [53], Mikheeva [62] as well as Carter and Bentley [63], $\pm 0.5 \%$ differences in PSD do not cause significant changes in soil functioning. Such changes can only marginally affect, e.g., soil compaction or/and air-water properties. The authors of some papers $[5,7,8]$ have stressed that high rates of different soil-applied materials, both mineral and organic ones, result in a significant change in particle size distribution. The soil texture is then restructured towards the one that is determined by the type of the material applied to the soil $[15,24,42]$.

Similarly to particle size distribution (PSD), particle density (PD) is a trait characterized by substantial stability [24,25,43,54]. In the present study, PD varied slightly from $2.56 \mathrm{Mg} \times \mathrm{m}^{-3}$ (BC30; layer 0-10 cm; sampling date I) to $2.64 \mathrm{Mg} \times \mathrm{m}^{-3}$ (BC0; layer 10-20 cm; sampling date 0) (Figure 1). Particle density of soil without biochar ranged from $2.62 \mathrm{Mg} \times \mathrm{m}^{-3}$ to $2.64 \mathrm{Mg} \times \mathrm{m}^{-3}$. PD in the $0-10 \mathrm{~cm}$ layer was higher than in the deeper layer of $10-20 \mathrm{~cm}$ almost in every case. Biochar application caused a distinct decrease in PD, which was proportional to the rate applied. The differences in PD results that were found immediately after biochar incorporation into the soil (sampling date I) between treatment $\mathrm{BC} 0$ and treatments $\mathrm{BC} 10, \mathrm{BC} 20$, and $\mathrm{BC} 30$ remained at a similar level until the end of the experiment (sampling date IX). It can therefore be concluded that biochar application caused persistent changes in PD (Figure 1, Table 1). These changes were found to be persistent in the case of both soil layers 
(0-10 $\mathrm{cm}$ and 10-20 cm) and each biochar rate. According to the arithmetic means, the biochar rates of $20 \mathrm{Mg} \times \mathrm{ha}^{-1}(\mathrm{BC} 20)$ and $30 \mathrm{Mg} \times \mathrm{ha}^{-1}$ (BC30) resulted in a significant decrease in PD in comparison with the control soil-BC0 (ANOVA-LSD) (Tables 2 and 3). Similar changes in soil particle density (PD) have also been obtained by other authors, e.g., Pranagal [8], Meena et al. [23], and Githinji [64]. In their studies, these authors used very high biochar rates-25-100\%,v/v. As a result, they found decrease to $40 \%$ PD. Nonetheless, these authors stressed that such a clear effect was short-lived (2-3 years). The relationships of PD with other soil properties, e.g., PSD, SOM, BD, FC, etc., are well known and have been frequently described by, among others, Jones [10], Reynolds et al. [24], Herath et al. [43], Blake and Hartge [54,55], Carter and Bentley [63], and Ball et al. [65].
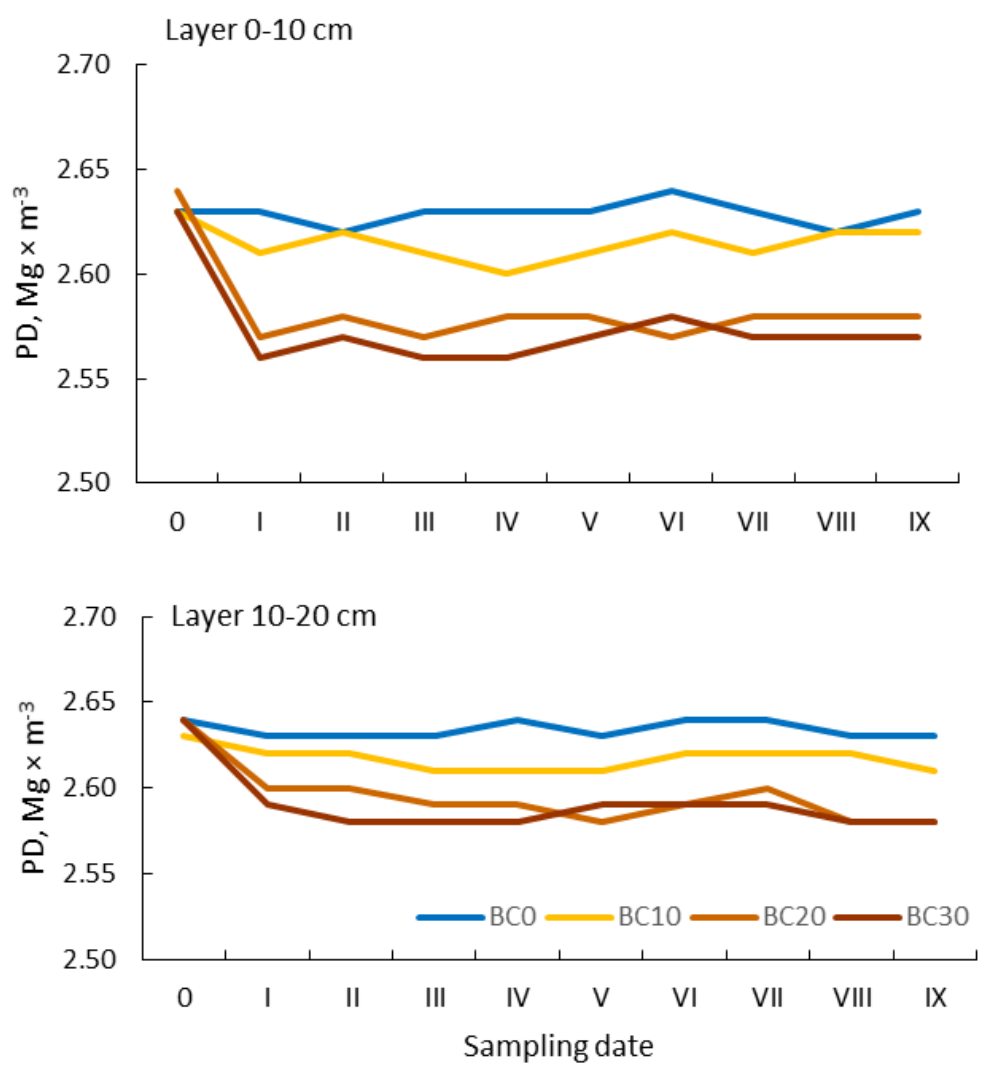

Figure 1. Particle density (PD). Explanations: $\mathrm{BC} 0$ — control: soil without application biochar; BC10 - soil with application biochar in the dose $10 \mathrm{Mg} \times \mathrm{ha}^{-1}$; $\mathrm{BC} 20$-soil with application biochar in the dose $20 \mathrm{Mg} \times \mathrm{ha}^{-1}$; BC30—soil with application biochar in the dose $30 \mathrm{Mg} \times \mathrm{ha}^{-1} ; 0, \mathrm{I}, \mathrm{III}, \ldots$, IX-sampling date (2010-2019). 
Table 1. The lowest significant differences $\left(\mathrm{LSD}_{0.05}\right)$ between treatments $(\mathrm{BC} 0, \mathrm{BC} 10, \mathrm{BC} 20$ and $\mathrm{BC} 30)$ for dates sampling $(0-\mathrm{IX})$ and studied layers $(0-10 \mathrm{~cm}$ and 10-20 cm).

\begin{tabular}{|c|c|c|c|c|c|c|c|c|c|c|c|}
\hline \multirow{2}{*}{$\begin{array}{l}\text { Sampling } \\
\text { Date }\end{array}$} & \multirow{2}{*}{$\begin{array}{l}\text { Soil Layer } \\
\text { (cm) }\end{array}$} & \multicolumn{10}{|c|}{ Soil Physical Properties } \\
\hline & & PD & BD & TP & FAC & FAP & SM & FC & AWC & UWC & $\mathrm{FC} / \mathrm{TP}$ \\
\hline \multirow{2}{*}{0} & $0-10$ & NS & NS & NS & NS & NS & NS & NS & NS & NS & NS \\
\hline & $10-20$ & NS & NS & NS & NS & NS & NS & NS & NS & NS & NS \\
\hline \multirow{2}{*}{ I } & $0-10$ & 0.047 & 0.137 & 0.1273 & 0.1382 & 26.32 & NS & 0.0447 & 0.0683 & 0.0096 & 0.143 \\
\hline & $10-20$ & 0.039 & 0.158 & 0.1582 & 0.0831 & NS & NS & 0.0714 & 0.0735 & 0.0081 & 0.123 \\
\hline \multirow{2}{*}{ II } & $0-10$ & 0.048 & 0.283 & 0.1574 & 0.1284 & 31.86 & 0.0438 & NS & NS & 0.0083 & 0.139 \\
\hline & $10-20$ & 0.037 & 0.191 & 0.0071 & 0.0634 & NS & 0.0381 & NS & NS & 0.0098 & 0.117 \\
\hline \multirow{2}{*}{ III } & $0-10$ & 0.053 & 0.139 & NS & NS & 19.23 & NS & NS & 0.0617 & 0.0078 & NS \\
\hline & $10-20$ & 0.036 & 0.153 & NS & NS & NS & NS & NS & 0.0513 & 0.0076 & 0.108 \\
\hline \multirow{2}{*}{ IV } & $0-10$ & 0.058 & NS & NS & NS & 18.11 & NS & NS & NS & 0.0073 & NS \\
\hline & $10-20$ & 0.043 & NS & NS & NS & NS & NS & 0.0491 & NS & 0.0086 & NS \\
\hline \multirow{2}{*}{ V } & $0-10$ & 0.049 & NS & NS & NS & 33.64 & 0.0362 & 0.0432 & NS & 0.0076 & 0.105 \\
\hline & $10-20$ & 0.042 & NS & NS & NS & 30.94 & 0.0413 & NS & NS & 0.0073 & NS \\
\hline \multirow{2}{*}{ VI } & $0-10$ & 0.051 & NS & NS & 0.0452 & 34.11 & NS & NS & NS & NS & 0.128 \\
\hline & $10-20$ & 0.042 & 0.153 & NS & NS & 16.29 & NS & NS & NS & 0.0066 & NS \\
\hline \multirow{2}{*}{ VII } & $0-10$ & 0.041 & NS & NS & NS & 26.31 & NS & NS & NS & 0.0074 & NS \\
\hline & $10-20$ & 0.043 & NS & NS & NS & NS & NS & NS & NS & 0.0068 & NS \\
\hline \multirow{2}{*}{ VIII } & $0-10$ & 0.043 & NS & NS & NS & 19.14 & NS & NS & NS & 0.0094 & NS \\
\hline & $10-20$ & 0.041 & NS & NS & NS & NS & NS & NS & NS & 0.0073 & NS \\
\hline \multirow{2}{*}{ IX } & $0-10$ & 0.049 & NS & NS & NS & NS & NS & NS & NS & 0.0098 & NS \\
\hline & $10-20$ & 0.044 & NS & NS & NS & NS & NS & NS & NS & 0.0084 & NS \\
\hline
\end{tabular}

Explanations: 0-IX—sampling date; PD—particle density $\left(\mathrm{Mg} \times \mathrm{m}^{-3}\right)$; BD—bulk density $\left(\mathrm{Mg} \times \mathrm{m}^{-3}\right)$; TP—total porosity $\left(\mathrm{m}^{3} \times \mathrm{m}^{-3}\right)$; FAC-air capacity at the potential $-15.5 \mathrm{kPa}\left(\mathrm{m}^{3} \times \mathrm{m}^{-3}\right)$; FAP—air permeability at the potential $-15.5 \mathrm{kPa}\left(10^{-8} \times \mathrm{m}^{2} \times \mathrm{Pa}^{-1} \times \mathrm{s}^{-1}\right)$; SM—soil moisture at sampling $\left(\mathrm{kg}^{2} \times \mathrm{kg}^{-1}\right)$; FC—field water capacity at the potential $-15.5 \mathrm{kPa}\left(\mathrm{m}^{3} \times \mathrm{m}^{-3}\right)$; AWC - available water content $\left(\mathrm{m}^{3} \times \mathrm{m}^{-3}\right)$; UWC—unavailable water content $\left(\mathrm{m}^{3} \times \mathrm{m}^{-3}\right)$; the FC/TP ratio; NS—no significant differences. 
Table 2. Mean values of soil physical properties for layers $(0-10 \mathrm{~cm}$ and $10-20 \mathrm{~cm})$ in the 2010-2019 years.

\begin{tabular}{|c|c|c|c|c|c|c|c|c|c|c|c|}
\hline \multirow{2}{*}{ Treatments } & \multirow{2}{*}{$\begin{array}{l}\text { Layers } \\
(\mathrm{cm})\end{array}$} & \multicolumn{10}{|c|}{ Soil Physical Properties } \\
\hline & & PD & BD & TP & FAC & FAP & SM & FC & AWC & UWC & $\mathrm{FC} / \mathrm{TP}$ \\
\hline \multirow{2}{*}{ ВC0 } & $0-10$ & $2.63 b$ & $1.59 \mathrm{ab}$ & $0.394 \mathrm{ab}$ & $0.143 a b$ & $19.1 \mathrm{ab}$ & $0.083 a$ & $0.252 \mathrm{ab}$ & $0.213 \mathrm{abc}$ & $0.039 a$ & $0.64 a$ \\
\hline & $10-20$ & $2.63 b$ & $1.66 \mathrm{~b}$ & $0.370 \mathrm{a}$ & $0.120 \mathrm{a}$ & $7.7 \mathrm{a}$ & $0.087 \mathrm{a}$ & $0.250 \mathrm{ab}$ & $0.211 \mathrm{abc}$ & $0.040 \mathrm{ab}$ & $0.68 \mathrm{bc}$ \\
\hline \multirow{2}{*}{ BC10 } & $0-10$ & $2.62 b$ & $1.57 \mathrm{ab}$ & $0.399 \mathrm{ab}$ & $0.161 \mathrm{ab}$ & $30.1 b$ & $0.087 \mathrm{a}$ & $0.238 \mathrm{a}$ & $0.197 \mathrm{a}$ & $0.041 \mathrm{abc}$ & $0.60 \mathrm{a}$ \\
\hline & $10-20$ & $2.62 b$ & $1.63 \mathrm{ab}$ & $0.375 a$ & $0.133 a b$ & $14.1 \mathrm{a}$ & $0.089 \mathrm{ab}$ & $0.242 a$ & $0.201 \mathrm{a}$ & $0.042 \mathrm{abc}$ & $0.64 a$ \\
\hline \multirow{2}{*}{ BC20 } & $0-10$ & $2.58 \mathrm{a}$ & $1.53 \mathrm{ab}$ & $0.408 \mathrm{ab}$ & $0.142 \mathrm{ab}$ & $30.2 b$ & $0.104 b c$ & $0.266 a b$ & $0.221 \mathrm{abc}$ & $0.045 \mathrm{abc}$ & $0.65 b$ \\
\hline & $10-20$ & $2.59 \mathrm{ab}$ & $1.62 \mathrm{ab}$ & $0.377 a$ & $0.108 \mathrm{a}$ & $21.9 \mathrm{ab}$ & $0.108 c$ & $0.269 b$ & $0.223 c$ & $0.046 \mathrm{abc}$ & $0.71 \mathrm{c}$ \\
\hline \multirow{2}{*}{ BC30 } & $0-10$ & $2.57 \mathrm{a}$ & $1.48 \mathrm{a}$ & $0.426 \mathrm{~b}$ & $0.171 b$ & $46.5 c$ & $0.103 \mathrm{ab}$ & $0.254 \mathrm{ab}$ & $0.207 a b$ & $0.047 \mathrm{c}$ & $0.60 \mathrm{a}$ \\
\hline & $10-20$ & $2.59 \mathrm{ab}$ & $1.54 \mathrm{ab}$ & $0.405 \mathrm{ab}$ & $0.133 a b$ & $22.1 \mathrm{ab}$ & $0.113 c$ & $0.272 b$ & $0.225 c$ & $0.047 \mathrm{c}$ & $0.66 \mathrm{bc}$ \\
\hline $\mathrm{LSD}_{0.05}$ & & 0.0471 & 0.149 & 0.0493 & 0.0497 & 15.43 & 0.0207 & 0.0295 & 0.0211 & 0.0063 & 0.048 \\
\hline
\end{tabular}

Explanations: BC0—control: soil without application biochar; BC10; BC20; BC30—-soil with application biochar in the dose 10, 20,30 Mg $\times$ ha $^{-1}$; PD—particle density $\left(\mathrm{Mg} \times \mathrm{m}^{-3}\right.$ ); BD—bulk density $\left(\mathrm{Mg} \times \mathrm{m}^{-3}\right)$; TP—-total porosity $\left(\mathrm{m}^{3} \times \mathrm{m}^{-3}\right)$; FAC—air capacity at the potential $-15.5 \mathrm{kPa}^{3}\left(\mathrm{~m}^{3} \times \mathrm{m}^{-3}\right)$; FAP—air permeability at the potential $-15.5 \mathrm{kPa}\left(10^{-8} \times \mathrm{m}^{2} \times \mathrm{Pa}^{-1} \times \mathrm{s}^{-1}\right)$; SM-soil moisture at sampling $\left(\mathrm{kg}^{2} \mathrm{~kg}^{-1}\right)$; FC—field water capacity at the potential $-15.5 \mathrm{kPa}\left(\mathrm{m}^{3} \times \mathrm{m}^{-3}\right)$; AWC—available water content $\left(\mathrm{m}^{3} \times \mathrm{m}^{-3}\right)$; UWC—unavailable water content $\left(\mathrm{m}^{3} \times \mathrm{m}^{-3}\right)$; the FC/TP ratio. Each letter $(\mathrm{a}, \mathrm{b}, \mathrm{c})$ means a significant difference (treatment $\times$ layer) according to Tukey's the lowest significant difference $\left(\mathrm{LSD}_{0.05}\right)$ and see Table 1. 
Table 3. Mean values of soil physical properties for treatments in the 2010-2019 years.

\begin{tabular}{llllll}
\hline \multirow{2}{*}{ Properties } & \multicolumn{5}{c}{ Treatments } \\
\cline { 2 - 5 } & BC0 & BC10 & BC20 & BC30 & LSD $_{\mathbf{0 . 0 5}}$ \\
\hline $\mathrm{PD}\left(\mathrm{Mg} \times \mathrm{m}^{-3}\right)$ & $2.63 \mathrm{~b}$ & $2.62 \mathrm{ab}$ & $2.59 \mathrm{a}$ & $2.58 \mathrm{a}$ & 0.043 \\
$\mathrm{BD}\left(\mathrm{Mg} \times \mathrm{m}^{-3}\right)$ & $1.63 \mathrm{~b}$ & $1.60 \mathrm{~b}$ & $1.57 \mathrm{ab}$ & $1.51 \mathrm{a}$ & 0.114 \\
$\mathrm{TP}\left(\mathrm{m}^{3} \times \mathrm{m}^{-3}\right)$ & $0.382 \mathrm{a}$ & $0.387 \mathrm{a}$ & $0.393 \mathrm{ab}$ & $0.416 \mathrm{~b}$ & 0.0242 \\
$\mathrm{FAC}\left(\mathrm{m}^{3} \times \mathrm{m}^{-3}\right)$ & $0.131 \mathrm{ab}$ & $0.147 \mathrm{ab}$ & $0.125 \mathrm{a}$ & $0.152 \mathrm{~b}$ & 0.0253 \\
$\mathrm{FAP}\left(10^{-8} \times \mathrm{m}^{2} \times \mathrm{Pa}^{-1} \times \mathrm{s}^{-1}\right)$ & $13.4 \mathrm{a}$ & $17.1 \mathrm{ab}$ & $26.1 \mathrm{bc}$ & $34.3 \mathrm{c}$ & 15.43 \\
$\mathrm{SM}\left(\mathrm{kg}^{\mathrm{k}} \mathrm{kg}^{-1}\right)$ & $0.085 \mathrm{a}$ & $0.088 \mathrm{a}$ & $0.106 \mathrm{~b}$ & $0.108 \mathrm{~b}$ & 0.0163 \\
$\mathrm{FC}\left(\mathrm{m}^{3} \times \mathrm{m}^{-3}\right)$ & $0.251 \mathrm{ab}$ & $0.240 \mathrm{a}$ & $0.268 \mathrm{~b}$ & $0.263 \mathrm{ab}$ & 0.0246 \\
$\mathrm{AWC}\left(\mathrm{m}^{3} \times \mathrm{m}^{-3}\right)$ & $0.212 \mathrm{ab}$ & $0.199 \mathrm{a}$ & $0.222 \mathrm{~b}$ & $0.216 \mathrm{ab}$ & 0.0203 \\
$\mathrm{UWC}\left(\mathrm{m}^{3} \times \mathrm{m}^{-3}\right)$ & $0.040 \mathrm{a}$ & $0.042 \mathrm{a}$ & $0.046 \mathrm{~b}$ & $0.047 \mathrm{~b}$ & 0.0032 \\
FC/TP & $0.66 \mathrm{~b}$ & $0.62 \mathrm{a}$ & $0.68 \mathrm{~b}$ & $0.63 \mathrm{a}$ & 0.0241 \\
\hline
\end{tabular}

Explanations as for Tables 1 and 2.

Bulk density (BD) is an important physical parameter considered to be one of the soil compaction measures [10-15]. The BD results obtained in this research were within a very wide range from $1.19 \mathrm{Mg} \times \mathrm{m}^{-3}$ (BC30; layer 0-10 cm; sampling date I) to $1.73 \mathrm{Mg} \times \mathrm{m}^{-3}$ (BC0; layer 10-20 cm; sampling date 0$)$ (Figure 2). As in the case of PD measurements, the topsoil layer $(0-10 \mathrm{~cm})$ was characterized by lower compaction than the 10-20 cm layer. The incorporated biochar definitely contributed to a decrease in BD. The higher the biochar rate, the more the BD decreased. The changes in bulk density related to both layers analyzed $(0-10 \mathrm{~cm}$ and $10-20 \mathrm{~cm})$. The differences between the soil in treatment $\mathrm{BC} 0$ and the soil in treatments $\mathrm{BC} 10, \mathrm{BC} 20$, and $\mathrm{BC} 30$, respectively, persisted only over three growing seasons (sampling dates I, II, and III). At sampling date IV, these differences disappeared completely (Table 1). In the next years (sampling dates V-IX), only differences that resulted rather from seasonal variation were observed (Figure 2). An analysis of variance (ANOVA-LSD) showed that only the differences in mean BD values between treatment $\mathrm{BC} 0$ and treatment $\mathrm{BC} 30$ could be considered significant (Tables 2 and 3). The obtained BD results were similar to those found by other authors, e.g., Pranagal et al. [8,15], Drewry et al. [12], Reynolds et al. [13,14], Arshad and Martin [66], Logson and Karlen [67], and McQueen and Shepherd [11]. They indicated that the bulk density of soils with the particle size distribution of loamy sands most frequently ranges from $1.50 \mathrm{Mg} \times \mathrm{m}^{-3}$ to $1.70 \mathrm{Mg} \times \mathrm{m}^{-3}$. These researchers also emphasized that favorable conditions for the growth of crop plants occur when $\mathrm{BD} \leq 1.60 \mathrm{Mg} \times \mathrm{m}^{-3}$. Based on the classification by Paluszek [68], the investigated soil was most often classified in the following BD classes: "medium" and "high". Therefore, one could expect excessive soil compaction and disturbances in soil-plant-atmosphere relations according to the specialists involved in research on the soil physical condition [8-15]. Such a situation occurred before the establishment of the experiment (sampling date 0 ) and also at successive sampling dates from the fifth year of the experiment (sampling date IV). Such soil condition was predominantly found in the deeper layer $(10-20 \mathrm{~cm}$ ) (Figure 2). The authors of similar studies [7-9,21-24,69] have also reported a deterioration in air-water conditions in the soil caused by a high BD. They underlined that the persistence of changes in the physical condition of the soil after its amendment with different additional materials was usually transient. 

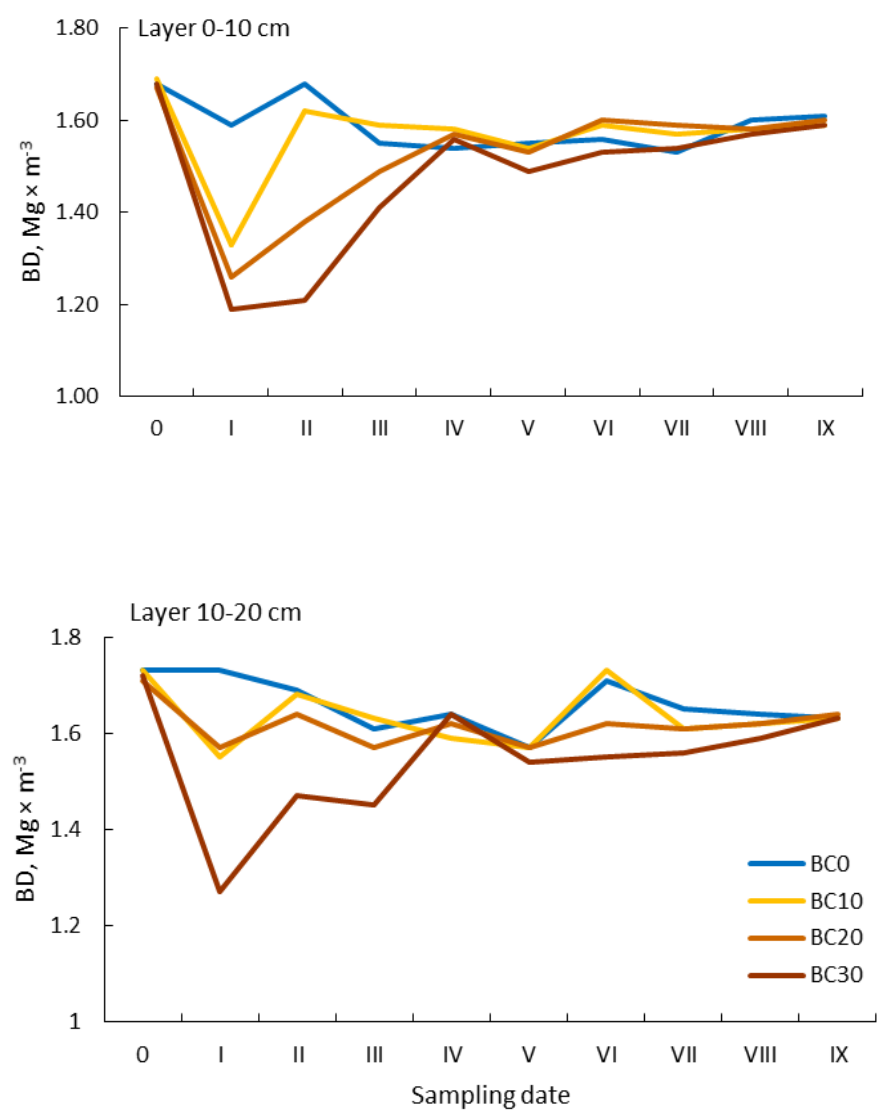

Figure 2. Bulk density (BD). Explanations as for Figure 1.

\subsection{Soil Total Porosity (TP) and Air Properties (FAC and FAP)}

Soil total porosity (TP) informs about the total volume of free spaces in the soil. It depends on the same factors that determine bulk density (BD). Their relationship is inversely proportional and many authors $[8-10,14,15,68,69]$ report a correlation coefficient $\mathrm{r} \approx-1.00$. The obtained TP results ranged from $0.345 \mathrm{~m}^{3} \times \mathrm{m}^{-3}$ (BC0; layer 10-20 $\mathrm{cm}$; sampling date 0) to $0.535 \mathrm{~m}^{3} \times \mathrm{m}^{-3}$ (BC30; layer 0-10 $\mathrm{cm}$; sampling date I) (Figure 3).

The TP results exhibited the same trends in changes as in the case of bulk density (BD). The addition of biochar, particularly at its highest rate (treatment $\mathrm{BC} 30$ ), had a significant effect on increasing total porosity (TP). The changes in TP applied to the entire arable soil layer $(0-20 \mathrm{~cm})$ to a similar degree. The differences due to biochar application persisted until the fifth year of the experiment (sampling date IV). At sampling date IV, the TP values equalized, while at subsequent dates (sampling dates V-IX) only small fluctuations in them were recorded (Table 1). According to the mean values, the TP of the soil amended with biochar at a rate of $30 \mathrm{Mg} \times \mathrm{ha}^{-1}$ (treatment BC30) was significantly highest (ANOVA-LSD) (Tables 2 and 3). Numerous papers on soil porosity $[9,13-15,63,68]$ have demonstrated that an ideal situation occurs in the soil when TP $\geq 0.500 \mathrm{~m}^{3} \times \mathrm{m}^{-3}$. According to the above cited authors, such TP should provide proper soil—plant—atmosphere relations. The studied soil was usually characterized by TP that was lower than its recommended optimum value (Figure 3 ). Other authors [42-46,68-71] have claimed that TP $\geq 0.500 \mathrm{~m}^{3} \times \mathrm{m}^{-3}$ is not sufficient to maintain optimal air-water conditions. They have also stressed that a favorable distribution of the network of soil pores and their patency are equally important as the total porosity (TP) of the soil.

Field air capacity (FAC) was calculated at a potential of $-15.5 \mathrm{kPa}$. Such energy state of the soil $(-15.5 \mathrm{kPa})$ was accepted as field water saturation of the soil. Then all pores with dimensions $>20 \mu \mathrm{m}-$ macropores are filled with air. Pores of this size perform an important role since they are 
responsible for gas exchange between the soil and the atmosphere. For this reason, they are often called aeration pores [56,68-71].
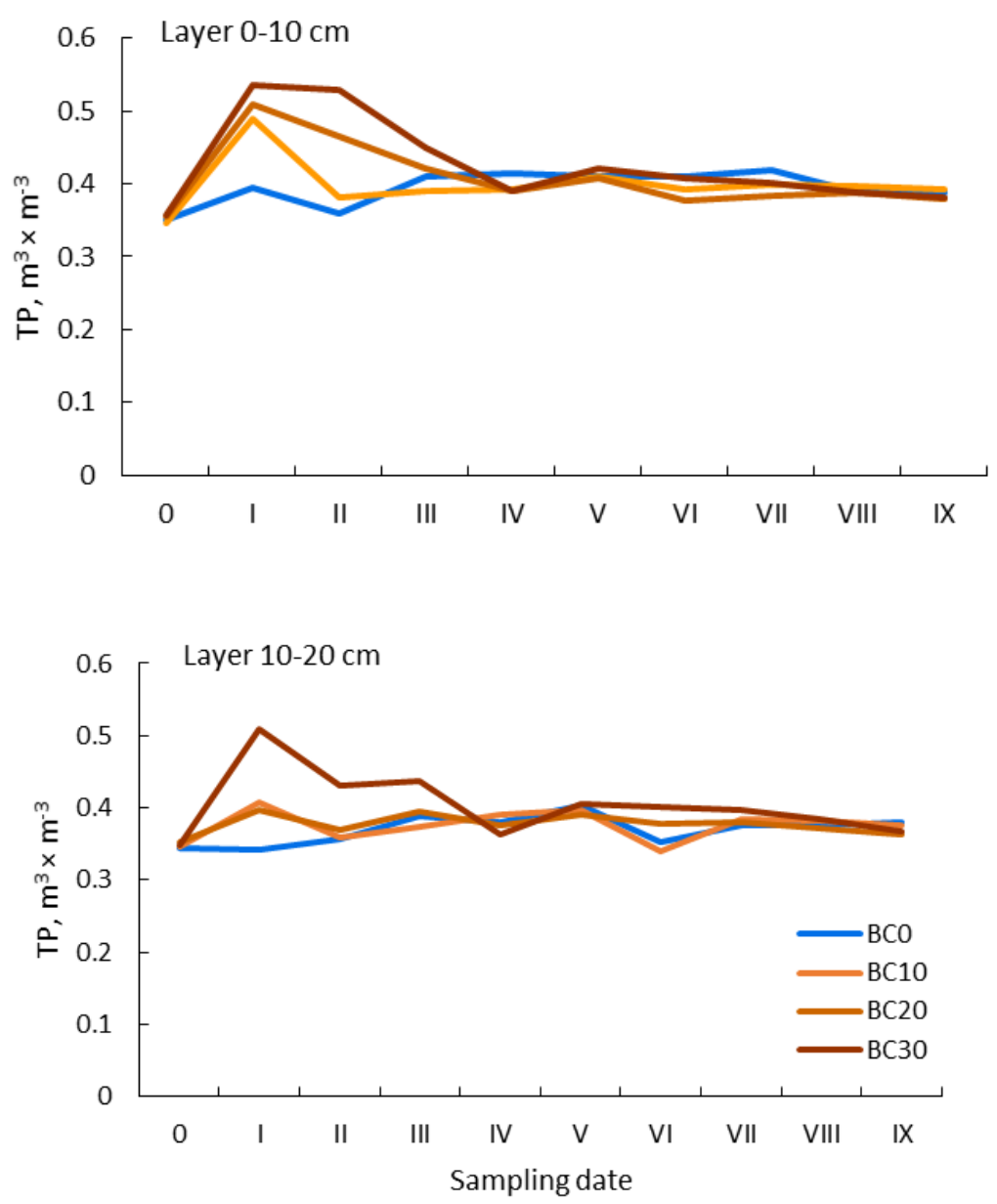

Figure 3. Total porosity (TP). Explanations as for Figure 1.

In our study, the FAC value was in the range from $0.092 \mathrm{~m}^{3} \times \mathrm{m}^{-3}$ (BCO; layer $10-20 \mathrm{~cm}$; sampling date 0) to $0.245 \mathrm{~m}^{3} \times \mathrm{m}^{-3}$ (BC30; layer 0-10 cm; sampling date II) (Figure 4). The effect of biochar application was visible only in the two first years-sampling dates I and II. Subsequently, the above-mentioned differences continued to decrease (Table 1). In the control treatment $(\mathrm{BC} 0)$, FAC was sometimes higher than in the biochar-amended soil (treatments $\mathrm{BC} 10, \mathrm{BC} 20$, and $\mathrm{BC} 30$ ). Such a situation occurred, for example, in: (i) layer 0-10 cm; sampling dates V and VI; and (ii) layer 10-20 cm; sampling dates III and V (Figure 4). It can be presumed that air capacity was more affected by the seasonal dynamics than biochar application. The analysis of variance (ANOVA-LSD) of the means revealed that significantly the lowest FAC was found in the soil in treatment BC20 (Tables 2 and 3). Many authors $[56,61,72,73]$ assume that FAC $>0.100 \mathrm{~m}^{3} \times \mathrm{m}^{-3}$ in order to provide proper soil aeration. On the other hand, some authors think that the threshold value of FAC should be higher, e.g., $>0.110 \mathrm{~m}^{3} \times \mathrm{m}^{-3}[14,74,75]$; $>0.120 \mathrm{~m}^{3} \times \mathrm{m}^{-3}$ [70], and $>0.140 \mathrm{~m}^{3} \times \mathrm{m}^{-3}[12,76,77]$. The above indicated threshold values of FAC apply to full water saturation of the soil at a potential of $-15.5 \mathrm{kPa}$ (FC) [59,60]. Under natural conditions, such a state occurs only several times during a growing season and it is a quickly receding state $[8,68,71,78]$. In most measurements, the studied soil met the criterion of FAC $>0.100 \mathrm{~m}^{3} \times \mathrm{m}^{-3}[56,61,72,73]$ as well as the minimum criterion proposed by Reynolds et al. [14,74] and Castellini et al. [75] $\left(>0.110 \mathrm{~m}^{3} \times \mathrm{m}^{-3}\right)$, Walczak et al. [70] $\left(>0.120 \mathrm{~m}^{3} \times \mathrm{m}^{-3}\right)$, Drewry et al. [12], Drewry [76], and Mueller et al. [77] $\left(>0.140 \mathrm{~m}^{3} \times \mathrm{m}^{-3}\right)$. When analyzing FAC results, one needs to remember that in the case of sandy soils a greater problem can be an excess 
of air, not its lack. After adding the biochar to the soil, the porosity (TP) increased (Figure 3), and its substantial part was occupied by macropores $(>20 \mu \mathrm{m})$. This situation was unfavorable because this caused excessive aeration of the soil. As a consequence, the soil could have become dry and soil organic matter mineralization could have accelerated $[1,4,8,63,66]$. It should be emphasized that in the case of the investigated soil the unfavorable changes only applied to sampling dates I and II. At the other sampling dates, i.e., dates III-IX, biochar was not found to have any negative impact on field air capacity (FAC).
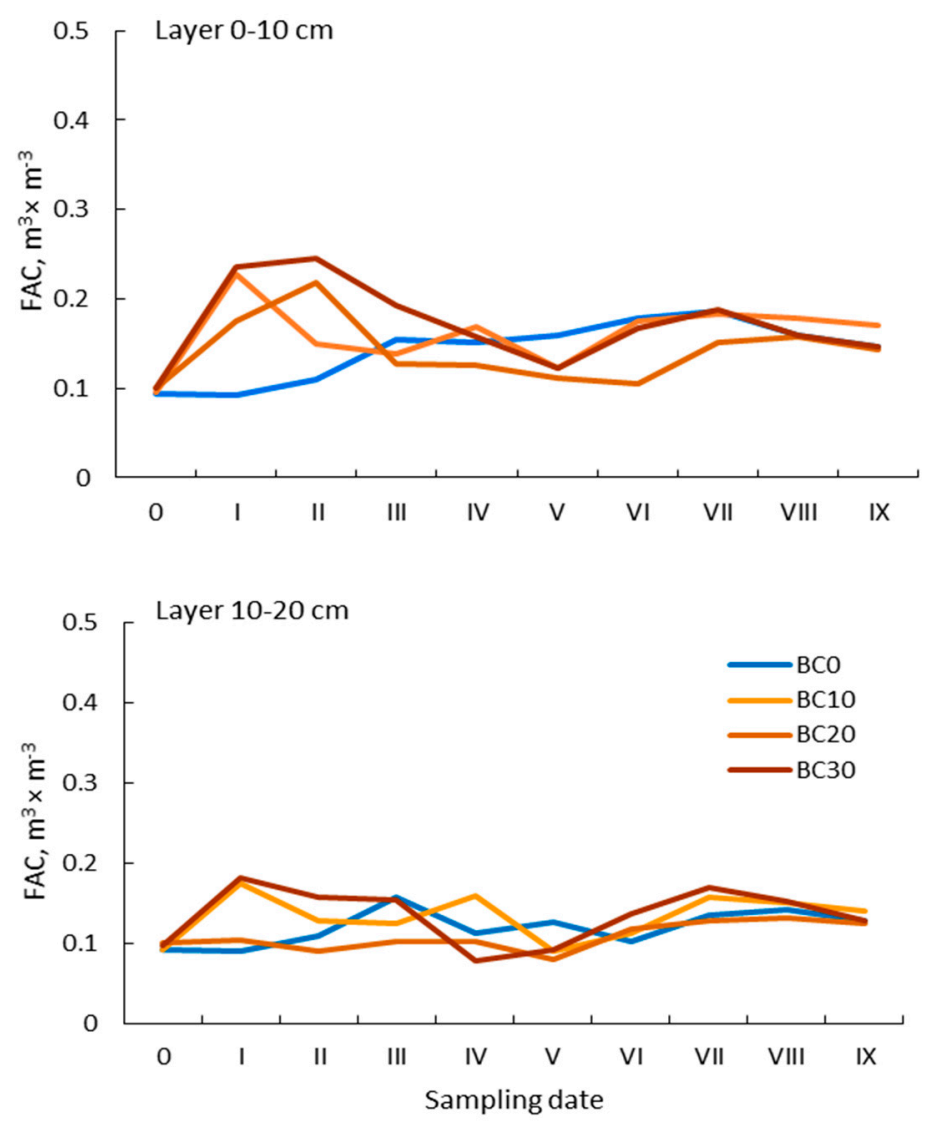

Figure 4. Air capacity at the potential $-15.5 \mathrm{kPa}(\mathrm{FAC})$. Explanations as for Figure 1.

Field air permeability (FAP) at full water saturation $(15.5 \mathrm{kPa})$ is an important parameter describing soil air properties. It characterizes the actual vertical gas flow in the soil and gas exchange between the soil and the atmosphere. FAP is a physical indicator of pore openness [79-81]. Measurements of FAP showed this parameter to vary significantly. Its value was within a wide range from $4.5 \times 10^{-8} \times \mathrm{m}^{2} \times \mathrm{Pa}^{-1} \times \mathrm{s}^{-1}$ (BC0; layer 10-20 cm; sampling date 0$)$ to $78.9 \times 10^{-8} \times \mathrm{m}^{2} \times \mathrm{Pa}^{-1} \times \mathrm{s}^{-1}$ (BC30; layer 0-10 cm; sampling date V). As in the case of FAC, higher values were recorded in the topsoil layer $(0-10 \mathrm{~cm})$, while smaller ones in the lower layer of 10-20 cm. The biochar's effect increasing the air permeability remained visible for eight years of the experiment (sampling dates I-VIII). In the last (tenth) year of the experiment (sampling date IX), the observed differences in FAP disappeared completely (Figure 5). 

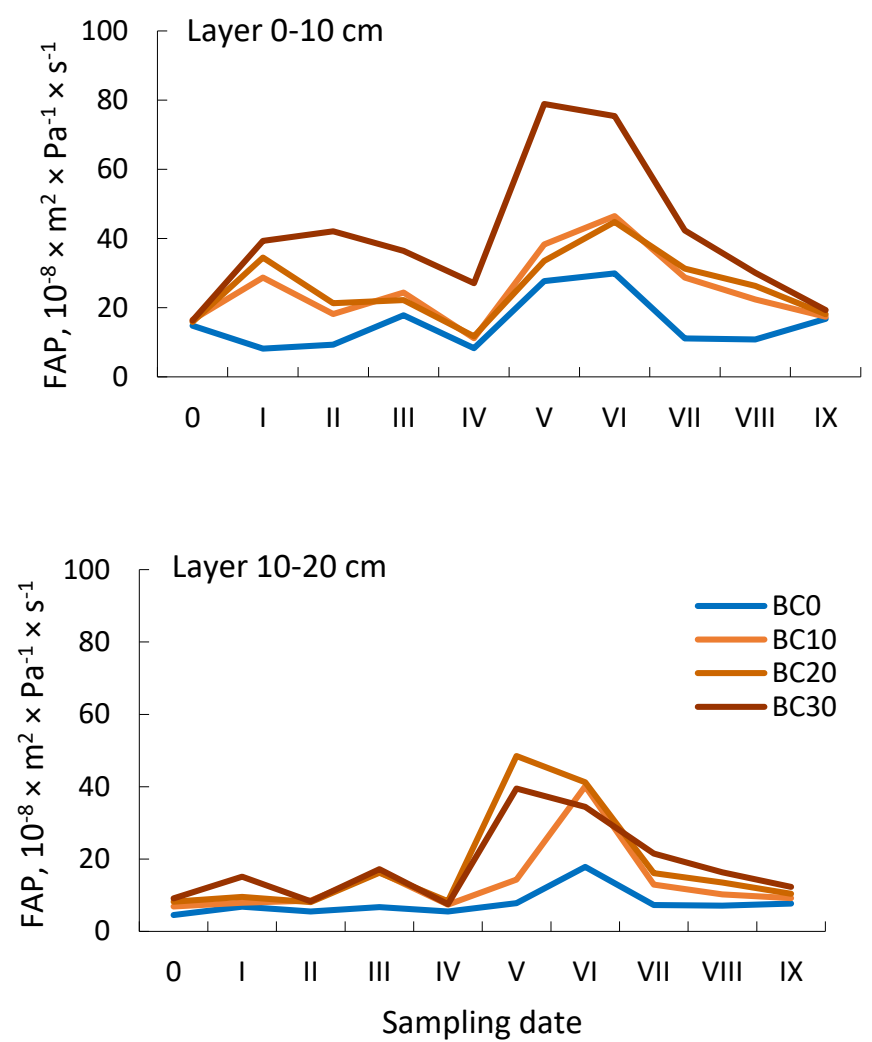

Figure 5. Air permeability at the potential $-15.5 \mathrm{kPa}$ (FAP). Explanations as for Figure 1.

The greatest differences in $\mathrm{FAP}$ values between the control treatment $\mathrm{BC} 0$ and the biochar addition treatments (BC10, BC20 and BC30) were found in the $0-10 \mathrm{~cm}$ layer at sampling dates $\mathrm{V}$ and $\mathrm{VI}$ (Figure 5). Given the above, a question arises why the largest range of FAP occurred not at sampling date I but at sampling date $\mathrm{V}$. A probable reason for such FAP results could have been the interaction of a number of soil physical characteristics, e.g., PD, BD, FAC, SM, FC, etc. The comparison of the mean FAP values in the analysis of variance and of significant differences (ANOVA-LSD) revealed that such differences occurred both between the layers $(0-10 \mathrm{~cm}$ and $10-20 \mathrm{~cm})$ and treatments $(\mathrm{BC} 0, \mathrm{BC} 10, \mathrm{BC} 20$ and $\mathrm{BC} 30)$ (Tables 1-3). FAP is a sensitive parameter for changes in the physical condition of the soil environment. It quickly responds to, e.g.: (i) modifications in the composition of individual soil components; (ii) fluctuations in soil moisture; and (iii) soil compaction. FAP also exhibits significant variations both within a single growing season and between seasons [82-84]. The studies by Paluszek [68] and Pranagal [71] demonstrated that proper gas flow in soil occurs when the vertical air permeability is at least $35.0 \times 10^{-8} \times \mathrm{m}^{2} \times \mathrm{Pa}^{-1} \times \mathrm{s}^{-1}$. This criterion was met by only $22 / 80$ cases of means from the FAP measurements in the studied soil. Based on the division of soils into quality classes of permeability proposed by the above-mentioned authors [68,71], the studied soil was most frequently (53/80 cases) classified in the "medium" class $\left(15-75 \times 10^{-8} \times \mathrm{m}^{2} \times \mathrm{Pa}^{-1} \times \mathrm{s}^{-1}\right)$, while only in $2 / 80$ cases this was the "high" class $\left(75-150 \times 10^{-8} \times \mathrm{m}^{2} \times \mathrm{Pa}^{-1} \times \mathrm{s}^{-1}\right)$. In the other cases, FAP was "low" $\left(2.5-15.0 \times 10^{-8} \times \mathrm{m}^{2} \times \mathrm{Pa}^{-1} \times \mathrm{s}^{-1}\right)$. An increase in FAP resulting from biochar application proved to be quite persistent, unlike the parameters describing soil compaction (BD, TP and FAC), for which the changes showed lower persistence. Most probably, this was primarily attributable to the greater patency of soil pores than in the control treatment $(\mathrm{BC} 0)$ and the presence of free interaggregate spaces and large intergrain pores. The authors of studies on soil air permeability $[68,71,79-84]$ have often indicated such a finding. The above cited papers also stressed some risks arising from a substantial increase in air permeability. Conditions for excessive aeration of the soil, and thus its drying, can then be created. 


\subsection{Soil Water Properties (SM, FC, AWC and UWC) and FC/TP Ratio}

The actual soil moisture (SM) is a very dynamic property. It predominantly depends on the amount of precipitation, evapotranspiration, and agronomic practices. During drought periods, it also tends to be dependent on: (i) soil texture; (ii) structure; and (iii) compaction [68-71,85]. The soil moisture (SM) during the experiment (2010-2019) was characterized by very high interseasonal variability. The SM values ranged from $0.059 \mathrm{~kg} \mathrm{~kg}^{-1}$ (BC0; layer 0-10 cm; sampling date IV) to $0.149 \mathrm{~kg} \mathrm{~kg}^{-1}$ (BC20; layer $10-20 \mathrm{~cm}$; sampling date $\mathrm{V}$ ). The effect of applied biochar on SM was particularly visible at sampling dates II, V, and VIII in both layers analyzed (Figure 6).
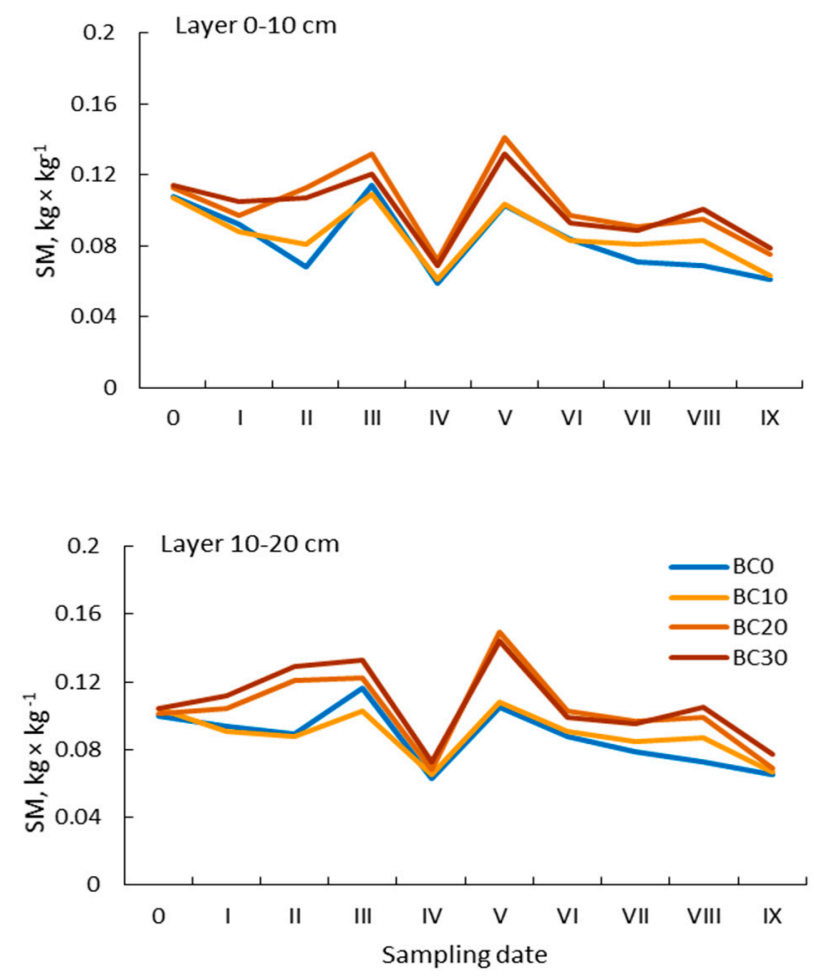

Figure 6. Soil moisture at sampling (SM). Explanations as for Figure 1.

A state can therefore be drawn that the effect of biochar application was only periodically positive (Table 1). The analysis of variance (ANOVA) and comparison of pairs of mean SM values (LSD) showed that significantly the least water was found in treatments BC0 and BC10 at sampling (Tables 1-3). Pandian et al. [86] informed that the effect of biochar incorporation into the soil was a $2.5 \%$ increase in its moisture. Recorded differences in SM can also be due to spatial variations that this characteristic is subject to. This applies to even small areas. It has been shown in papers by, among others, White [85], Kutílek [87], Leśny [88], Petrosyants et al. [89] as well as Usowicz and Usowicz [90]. It should be underlined that this experiment was conducted in an area with dominant rainfall-based water management. Hence, SM was primarily dependent on the amount and distribution of precipitation and air temperature $[85,88,89]$. These factors cause recurrent soil wetting and drying cycles, while during the winter period freeze and thaw cycles. The cyclicity of these processes promotes the formation of soil aggregates [68,71,91-93].

In the case of the determined field water capacity-FC $(-15.5 \mathrm{kPa})$, the effect of adding the biomass processed through pyrolysis to the soil proved to be consistent with the soil compaction results (BD and TP) and the aeration properties (FAC and FAP). FC showed values characterized by quite large variations. They were in the range from $0.230 \mathrm{~m}^{3} \times \mathrm{m}^{-3}$ (BC0; layer 10-20 $\mathrm{cm}$; sampling date III) to $0.329 \mathrm{~m}^{3} \times \mathrm{m}^{-3}$ (BC30; layer 10-20 cm; sampling date I) (Figure 7). 

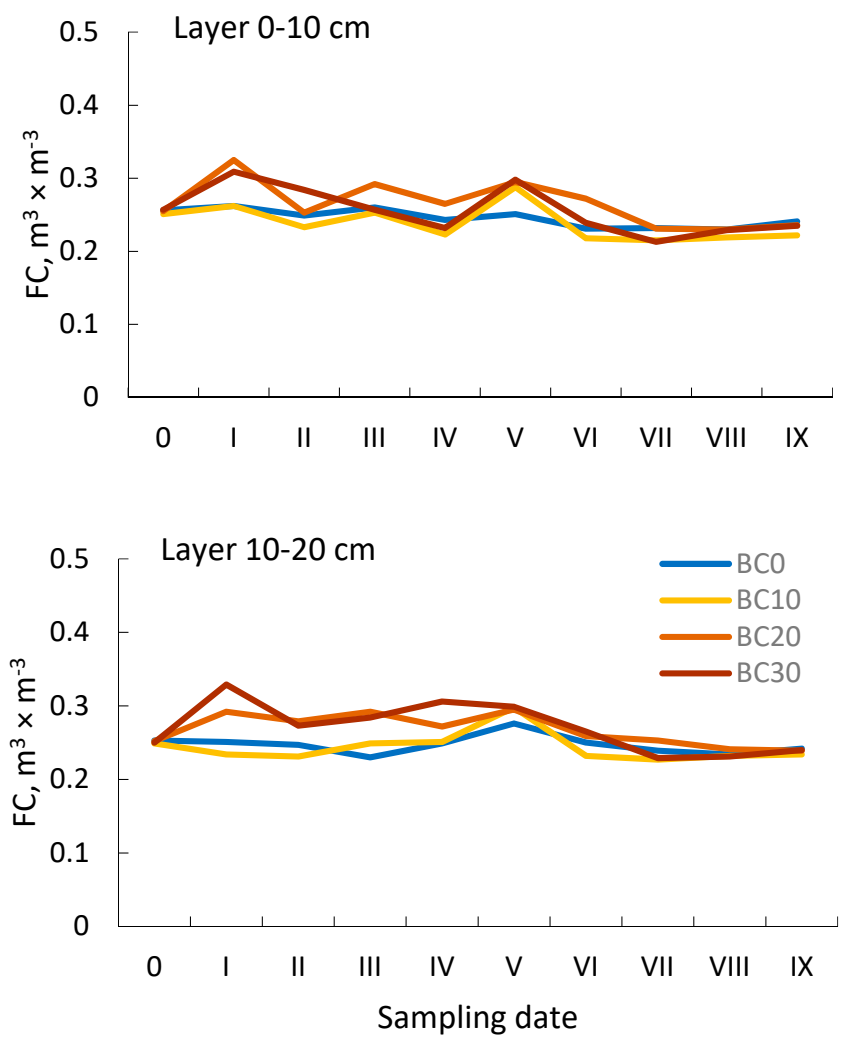

Figure 7. Field water capacity at the potential $-15.5 \mathrm{kPa}(\mathrm{FC})$. Explanations as for Figure 1.

Small but visible variations in FC values were recorded from sampling date I to sampling date VII. However, they were usually greater in the deeper layer of $10-20 \mathrm{~cm}$. This was also confirmed by the analysis of variance (ANOVA-LSD) which revealed significantly the highest FC values in the $10-20 \mathrm{~cm}$ layer. On the other hand, in the comparison of pairs of means in the treatments $(\mathrm{BC} 0, \mathrm{BC} 10$, $\mathrm{BC} 20$, and $\mathrm{BC} 30$ ), significantly the highest FC was found for the soil in treatment BC20 (Tables 2 and 3). The differences in FC results due to biochar application persisted for seven years (sampling dates I-VII). Subsequently, they began to disappear definitely from sampling date VII (Figure 7, Table 1). When assessing the field water capacity (FC) of the studied soil, it can be classified in the "medium" class according to the classification by Walczak et al. [70]. Nonetheless, when we take into account the recommendations given by Reynolds et al. [14], the obtained results were close to the determined optimum FC $\left(0.300-0.350 \mathrm{~m}^{3} \times \mathrm{m}^{-3}\right)$ only in several situations. The obtained results confirmed the strong dependence of FC on soil compaction (Figures 2, 3 and 7) [63]. This dependence has also been described in experiments carried out in soils of other types $[8,13,21,22,42,43]$.

In the context of ensuring stable yields, a very important parameter of the soil physical condition is available water content (AWC) $[14,68,70,94,95]$. Over the 10-year measurements (2010-2019), the AWC values were in a rather wide range from $0.181 \mathrm{~m}^{3} \times \mathrm{m}^{-3}$ (BC30; layer 10-20 cm; sampling date VII) to $0.290 \mathrm{~m}^{3} \times \mathrm{m}^{-3}$ (BC20; layer 0-10 $\mathrm{cm}$; sampling date II). The nature of the changes was the same as in the case of FC (Figures 7 and 8, Table 1). 

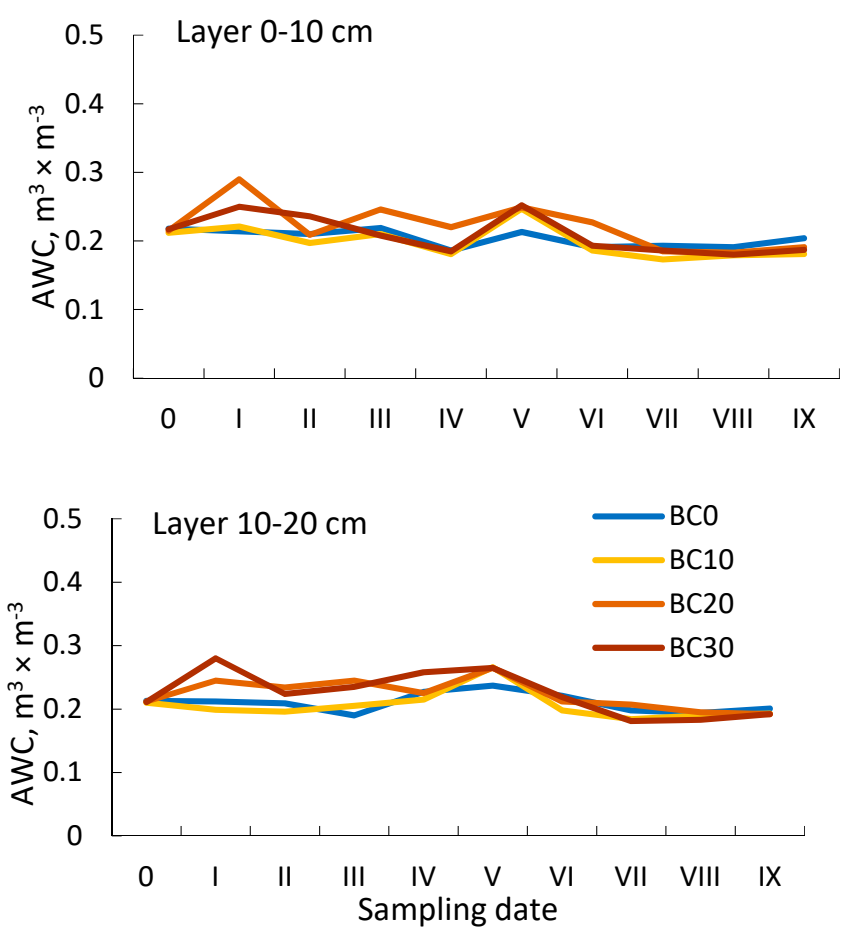

Figure 8. Available water content (AWC). Explanations as for Figure 1.

The analysis of variance and comparison of pairs of AWC means (ANOVA-LSD) showed that the $10-20 \mathrm{~cm}$ soil layer in treatments $\mathrm{BC} 20$ and $\mathrm{BC} 30$ had significantly the best retention properties, while as regards the entire arable layer $(0-20 \mathrm{~cm})$, the soil in treatment BC20 retained most water (Tables 2 and 3). Visible differences in AWC for the analyzed treatments were also observed during measurements at sampling date VII (Figure 8). In the subsequent years of the experiment (sampling dates VIII and IX), the previously observed differences disappeared. Similar observations regarding an increase in stocks of water and its availability to plants as a direct result of biochar incorporation into the soil have also been reported by Abel et al. [42]—sandy soil, Pranagal et al. [8]—-loamy sand soil, Githinji [64]—sandy loam soil, Herath et al. [43]—-loamy soils (Alfisol and Andisol), Lu et al. [96]—clayey soil (Vertisol) as well as by Omondi et al. in a meta-analysis [46]. Evaluation of the obtained AWC results allow us to state that the studied soil was characterized by good retention properties. According to Walczak et al. [70], in terms of AWC values the investigated soil could be classified in the "high" class $\left(\geq 0.210 \mathrm{~m}^{3} \times \mathrm{m}^{-3}\right.$-in $43 / 80$ cases) and also in the "medium" class $\left(0.120-0.210 \mathrm{~m}^{3} \times \mathrm{m}^{-3}-37 / 80\right)$. In accordance with the proposals of Reynolds et al. [14] and Castellini et al. [75], on the other hand, the analyzed soil was assessed as "ideal" ( $\geq 0.200 \mathrm{~m}^{3} \times \mathrm{m}^{-3}$-in $49 / 80$ cases), while in many cases also as "good" $\left(0.150-0.200 \mathrm{~m}^{3} \times \mathrm{m}^{-3}-31 / 80\right)$. The changes in AWC caused by biochar application were found over a period of seven years. They were most frequently beneficial, though small.

The unavailable water content (UWC) was typical of soils with the particle size distribution of loamy sand (LS) and with a low organic carbon content [8,63,68-71]. The biochar incorporated into the soil resulted in a visible and persistent increase in UWC in micropores $(<0.2 \mu \mathrm{m})$. During the measurement period, UWC ranged from $0.037 \mathrm{~m}^{3} \times \mathrm{m}^{-3}$ (BC0; layer 0-10 $\mathrm{cm}$; sampling date 0 ) to $0.049 \mathrm{~m}^{3} \times \mathrm{m}^{-3}$ (BC30; layer 0-10 cm; sampling date I). The range of UWC results of similar magnitude $\left(0.06-0.010 \mathrm{~m}^{3} \times \mathrm{m}^{-3}\right)$ persisted over the nine years of the experiment (sampling dates I-IX). The changes in the unavailable water content applied to both soil layers analyzed and were proportional to the amount of biochar applied (10, 20, and $30 \mathrm{Mg} \times \mathrm{ha}^{-1}$ ) (Figure 9). This was confirmed by the analysis of variance (ANOVA-LSD) which revealed that significantly the highest UWC was in treatments BC20 and BC30 (Tables 1-3). The studied soil was characterized by a small percentage of UWC in FC. On average, this percentage did not exceed $20 \%$. The comparison of the FC, AWC, and UWC results allowed finding that the biochar added to the soil had a positive effect. The increase in FC was primarily due 
to the increase in AWC arising from an increased content of mesopores $(0.2-20.0 \mu \mathrm{m})$. It is worth stressing that the volume of micropores $(<0.2 \mu \mathrm{m})$, in comparison with the volume of macropores $(>20.0 \mu \mathrm{m})$ and mesopores $(0.2-20.0 \mu \mathrm{m})$, showed much smaller variations. Similar observations have also been described by the authors of other experiments $[5,8,22,24,25,46,78,88]$. Nevertheless, the above-mentioned authors emphasized that the effect of biochar application was short-lived and most frequently limited to the topsoil layer $(0-10 \mathrm{~cm})$.

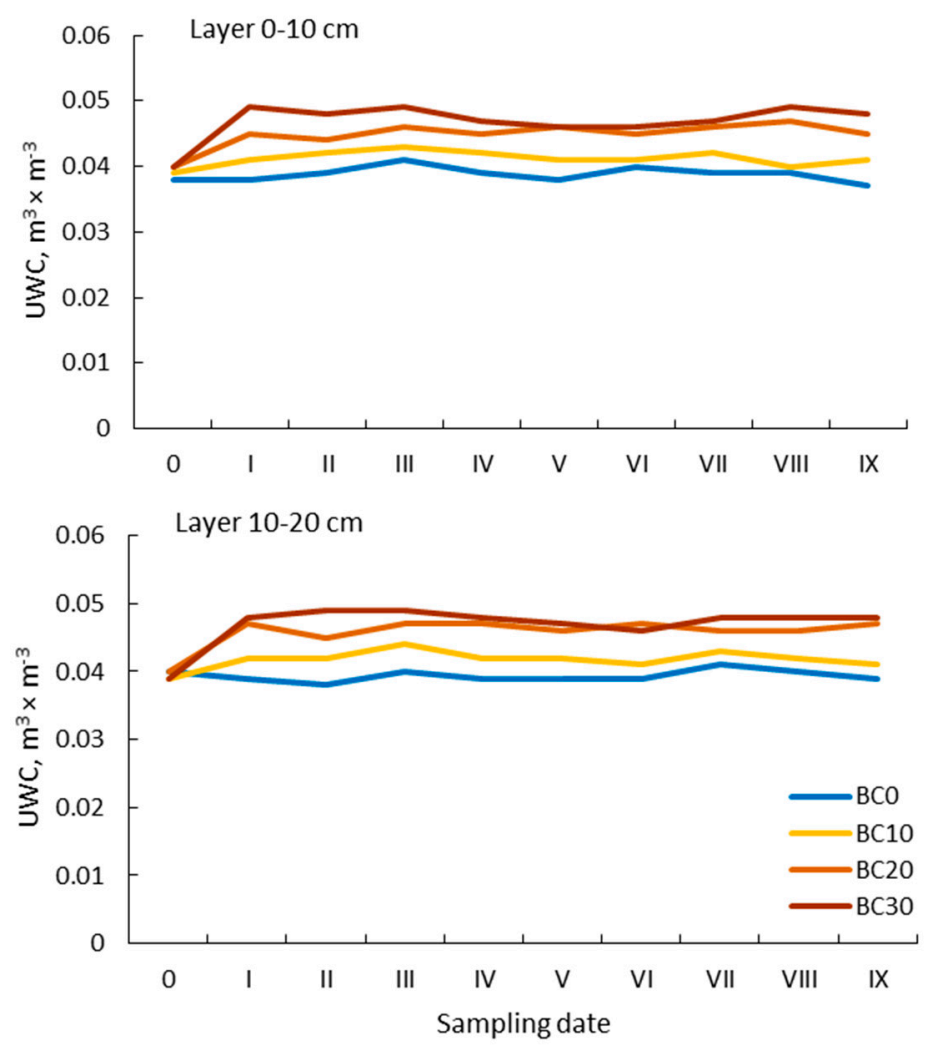

Figure 9. Unavailable water content (UWC). Explanations as for Figure 1.

During the ten-year experiment (2010-2019), air-water conditions in the soil were also evaluated. To this end, the FC/TP ratio was determined, which underwent quite numerous changes. They applied to all treatments $(\mathrm{BC} 0, \mathrm{BC} 10, \mathrm{BC} 20$ and $\mathrm{BC} 30)$. These changes resulted not only from the addition of biochar to the soil, but also from seasonal variation. The FC/TP value ranged from 0.53 (BC10; layer 0-10 cm; sampling date I) to 0.74 (BC20; layer 10-20 cm; sampling date III) (Figure 10). In the control treatment $(\mathrm{BC} 0)$, air-water conditions were most stable - the FC/TP ratio value ranged from 0.56 to 0.73 . The calculated mean FC/TP values for all treatments were within the optimum range, i.e., $0.60-0.70[14,60,61,63,74,75]$. The analysis of variance (ANOVA-LSD) showed that significantly the lowest FC/TP values were found for the soil in treatment BC10 (Tables 1-3). It should however be stressed that periods when the FC/TP ratio diverged from its optimum value $(0.60-0.70)$ were found with regard to the soil in all experimental treatments. Both the appearance of aeration impairment conditions (FC/TP > 0.70) and the condition of the soil signifying its excessive aeration, and thus a periodic water deficit $(\mathrm{FC} / \mathrm{TP}<0.60)$, could be found. 

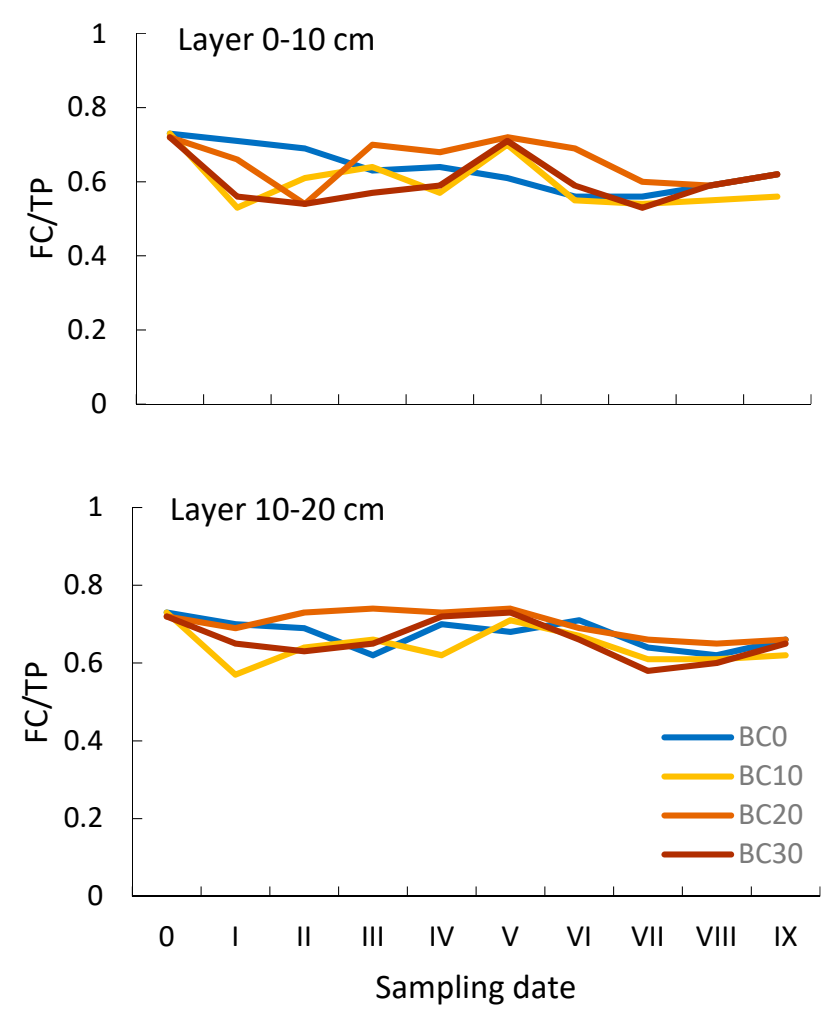

Figure 10. Ratio of field water capacity and total porosity (FC/TP). Explanations as for Figure 1.

\section{Conclusions}

The analysis of the obtained results allowed us to verify the hypothesis that one-time biochar amendment contributes to an improvement in soil physical properties and that resultant changes in soil properties are persistent. To this end, the range and persistence of changes in soil properties caused by agricultural use of biochar produced from waste winter wheat straw were evaluated in this study. A conclusion can be drawn that biochar application of $\mathrm{BC} 10, \mathrm{BC} 20$, and $\mathrm{BC} 30$ did improve soil physical properties, that is, the particle density (PD) and bulk density (BD) decreased, while the total porosity (TP) increased. The positive changes in PD, BD and TP also had an effect on increasing the following parameters: water content at sampling (SM), air capacity at $-15.5 \mathrm{kPa}(\mathrm{FAC})$, air permeability at $-15.5 \mathrm{kPa}(\mathrm{FAP})$, field water capacity at $-15.5 \mathrm{kPa}(\mathrm{FC})$, available water content (AWC), unavailable water content (UWC), and FC/TP ratio. It should however be remembered that an increase in soil air capacity and air permeability is not always positive. A large increase in the value of these traits can lead to unfavorable changes in air-water relations, i.e., to excessive aeration of the soil or even to its drying. Such a situation may apply in particular to poor quality soils with the sandy texture. The changes in the physical properties of soil described in this study, although visible, cannot be considered as permanent. Statistical analysis confirmed that only two soil properties has changed permanently: particle density (PD) and unavailable water content (UWC). Most of the analyzed properties showed a durability of no more than 3-4 years. We also found that biochar incorporation into soil is a good way for environmental management of waste biomass. The results presented by us and the observations collected during the experiment demonstrate that environmental management of biochar requires very great caution. When incorporating this type of waste into soil, one needs to remember not to disturb the balance in soil functions, i.e., the "container" and "filter" functions. To determine the timing for repeated agricultural, but safe use of waste, we propose to continue soil monitoring in subsequent years.

Author Contributions: J.P., P.K., conceptualized the research; P.K., J.P., designed the research; J.P., P.K., performed the experiments; J.P. analyzed the data; J.P., P.K., wrote the paper. All authors have read and agreed to the published version of the manuscript. 
Funding: This research was funded by the Ministry of Science and Higher Education, Poland.

Conflicts of Interest: This research was funded by the Ministry of Science and Higher Education, Poland. The authors declare no conflict of interest. The funders had no role in the design of the study; in the collection, analyses or interpretation of data; in the writing of the manuscript, or in the decision to publish the results.

\section{References}

1. Blum, W.E.H. Basic concepts: Degradation, resilience, and rehabilitation. In Methods for Assessment of Soil Degradation; CRC Press: Boca Raton, FL, USA, 1998.

2. Lal, R. Soil and sustainability agriculture. A review. Agron. Sustain. Dev. 2008, 28, 57-65. [CrossRef]

3. Lal, R. Soils and world food security. Soil Tillage Res. 2009, 102, 1-4. [CrossRef]

4. Lorenz, K.; Lal, R.; Ehlers, K. Soil organic carbon stock as an indicator for monitoring land and soil degradation in relation to United Nations' Sustainable Development Goals. Land Degrad. Dev. 2019, 30, 824-838. [CrossRef]

5. Ajayi, A.E.; Holthusen, D.; Horn, R. Changes in microstructural behaviour and hydraulic functions of biochar amended soils. Soil Tillage Res. 2016, 155, 166-175. [CrossRef]

6. Baran, S.; Pranagal, J.; Bik, M. Usefulness of mineral wool Grodan and sewage sludge in management of water properties in soils devastated during extraction of sulphur by Frash method. Miner. Resour. Manag. 2008, 24, 81-95.

7. Pranagal, J.; Domżał, H.; Słowińska-Jurkiewicz, A.; Świca, M.; Zawiślak-Pranagal, M. Effect of popectin spent grains on soil filtration properties. Acta Agrophys. 2002, 70, 277-286.

8. Pranagal, J.; Oleszczuk, P.; Tomaszewska-Krojańska, D.; Kraska, P.; Różyło, K. Effect of biochar application on the physical properties of Haplic Podzol. Soil Tillage Res. 2017, 174, 92-103. [CrossRef]

9. Pranagal, J.; Ligęza, S.; Smal, H. Impact of Effective Microorganisms (EM) application on the physical condition of Haplic Luvisol. Agronomy 2020, 10, 1049. [CrossRef]

10. Jones, C.A. Effect of soil texture on critical bulk densities for root growth. Soil Sci. Soc. Am. J. 1983, 47, 1208-1212. [CrossRef]

11. McQueen, D.J.; Shepherd, T.G. Physical changes and compaction sensitivity of a fine textured, poorly drained soil (Typic endoaquept) under varying durations of cropping, Manawatu Region, New Zealand. Soil Tillage Res. 2002, 63, 93-107. [CrossRef]

12. Drewry, J.J.; Cameron, K.C.; Buchan, G.D. Pasture yield and soil physical property responses to soil compaction from treading and grazing-A review. Aust. J. Soil Res. 2008, 46, 237-256. [CrossRef]

13. Reynolds, W.D.; Bowman, B.T.; Drury, C.F.; Tan, C.S.; Lu, X. Indicators of good soil physical quality: Density and storage parameters. Geoderma 2002, 110, 131-146. [CrossRef]

14. Reynolds, W.D.; Drury, C.F.; Yang, X.M.; Tan, C.S. Optimal soil physical quality inferred through structural regression and parameter interactions. Geoderma 2008, 146, 466-474. [CrossRef]

15. Pranagal, J.; Tomaszewska-Krojańska, D.; Smal, H.; Ligęza, S. Impact of selected waste applications on soil compaction. Agron. Sci. 2019, 74, 19-32. [CrossRef]

16. Edwards, C.A. Assessing the effects of environmental pollutants on soil organisms, communities, processes and ecosystems. Eur. J. Soil Biol. 2002, 38, 225-231. [CrossRef]

17. Van-Camp, L.; Bujarrabal, B.; Gentile, A.R.; Jones, R.J.A.; Montanarella, L.; Olazabal, C.; Selvaradjou, S.K. Reports of the Technical Working Groups Established under the Thematic Strategy for Soil Protection; EUR 21319 EN/3; Office for Official Publications of the European Communities: Luxembourg, 2004; pp. 311-496.

18. Angers, D.A.; Eriksen-Hamel, N.S. Full-inversion tillage and organic carbon distribution in soil profiles: A meta-analysis. Soil Sci. Soc. Am. J. 2008, 72, 1370-1374. [CrossRef]

19. Hillel, D.; Rosenzweig, C. Conclusion: Agricultural solutions for climate change at global and regional scales. In Handbook of Climate Change and Agroecosystems: Global and Regional Aspects and Implications; ICP Series on Climate Change Impacts, Adaptation, and Mitigation 2; Hillel, D., Rosenzweig, C., Eds.; Imperial College Press: London, UK, 2012; pp. 281-292.

20. Lal, R. Restoring Soil Quality to Mitigate Soil Degradation. Sustainability 2015, 7, 5875-5895. [CrossRef]

21. Ojeda, G.; Mattana, S.; Bonmati, M.; Woche, S.K.; Bachmann, J. Soil wetting-drying and water-retention properties in a mine-soil treated with composted and thermally-dried sludges. Eur. J. Soil Sci. 2011, 62, 696-708. [CrossRef] 
22. Ojeda, G.; Mattana, S.; Àvila, A.; Alcañiz, J.M.; Volkmann, M.; Bachmann, J. Are soil-water functions affected by biochar application? Geoderma 2015, 249, 1-11. [CrossRef]

23. Meena, R.S.; Lal, R.; Yadav, G.S. Long-term impacts of topsoil depth and amendments on soil physical and hydrological properties of an Alfisol in central Ohio, USA. Geoderma 2020, 363, 114164. [CrossRef]

24. Reynolds, W.D.; Nurse, R.; Phillips, L.; Drury, C.F.; Yang, X.M.; Page, E.R. Characterizing mass-volume-density-porosity relationships in a sandy loam soil amended with compost. Can. J. Soil Sci. 2020, 100, 1-13. [CrossRef]

25. Amoah-Antwi, C.; Kwiatkowska-Malina, J.; Thornton, S.F.; Fenton, O.; Malina, G.; Szara, E. Restoration of soil quality using biochar and brown coal waste: A review. Sci. Total Environ. 2020, 722, 137852. [CrossRef] [PubMed]

26. Różyło, K.; Oleszczuk, P.; Jośko, I.; Kraska, P.; Kwiecińska-Poppe, E.; Andruszczak, S. An ecotoxicological evaluation of soil fertilized with biogas residues or mining waste. Environ. Sci. Poll. Res. 2015, 22, 7833-7842. [CrossRef] [PubMed]

27. Różyło, K.; Gawlik-Dziki, U.; Świeca, M.; Różyło, R.; Pałys, E. Winter wheat fertilized with biogas residue and mining waste: Yielding and the quality of grain. J. Sci. Food Agric. 2016, 96, 3454-3461. [CrossRef]

28. Bandara, T.; Franks, A.; Xu, J.; Bolan, N.; Wang, H.; Tang, C. Chemical and biological immobilization mechanisms of potentially toxic elements in biochar-amended soils. Crit. Rev. Environ. Sci. Technol. 2020, 50, 903-978. [CrossRef]

29. Chen, H.; Yang, X.; Wang, H.; Sarkar, B.; Shaheen, S.M.; Gielen, G.; Bolan, N.; Guo, J.; Che, L.; Sun, H.; et al. Animal carcass- and wood-derived biochars improved nutrient bioavailability, enzyme activity, and plant growth in metal-phthalic acid ester co-contaminated soils: A trial for reclamation and improvement of degraded soils. J. Environ. Manag. 2020, 261, 110246. [CrossRef] [PubMed]

30. Wang, H.; Baek, K.; Xue, J.; Li, Y.; Beiyuan, J. Preface-Biochar and agricultural sustainability. J. Soils Sediments 2020, 20, 3015-3016. [CrossRef]

31. Wu, P.; Ata-Ul-Karim, S.T.; Singh, B.P.; Wang, H.; Wu, T.; Liu, C.; Fang, G.; Zhou, D.; Wang, Y.; Chen, W. A scientometric review of biochar research in the past 20 years (1998-2018). Biochar 2019, 1, 23-43. [CrossRef]

32. Li, Y.F.; Hu, S.D.; Chen, J.H.; Muller, K.; Li, Y.C.; Fu, W.J.; Lin, Z.W.; Wang, H.L. Effects of biochar application in forest ecosystems on soil properties and greenhouse gas emissions: A review. J. Soils Sediments 2018, 18, 546-563. [CrossRef]

33. Aydin, E.; Šimanský, V.; Horák, J.; Igaz, D. Potential of Biochar to Alternate Soil Properties and Crop Yields 3 and 4 Years after the Application. Agronomy 2020, 10, 889. [CrossRef]

34. Seleiman, M.F.; Alotaibi, M.A.; Alhammad, B.A.; Alharbi, B.M.; Refay, Y.; Badawy, S.A. Effects of ZnO Nanoparticles and Biochar of Rice Straw and Cow Manure on Characteristics of Contaminated Soil and Sunflower Productivity, Oil Quality, and Heavy Metals Uptake. Agronomy 2020, 10, 790. [CrossRef]

35. Fang, Z.; Gao, Y.; Bolan, N.; Shaheen, S.M.; Xu, S.; Wu, X.; Xu, X.; Hu, H.; Lin, J.; Zhang, F.; et al. Conversion of biological solid waste to graphene-containing biochar for water remediation: Acritical review. Chem. Eng. J. 2020, 390, 124611. [CrossRef]

36. Lu, L.; Yu, W.; Wang, Y.; Zhang, K.; Zhu, X.; Zhang, Y.; Wu, Y.; Ullah, H.; Xiao, X.; Chen, B. Application of biochar-Based materials in environmental remediation: From multi-level structures to specific devices. Biochar 2020, 2, 1-31. [CrossRef]

37. Zhang, X.; Gao, B.; Fang, J.; Zou, W.; Dong, L.; Cao, C.; Zhang, J.; Li, Y.; Wang, H. Chemically activated hydrochar as an effective adsorbent forvolatile organic compounds (VOCs). Chemosphere 2019, 218, 680-686. [CrossRef]

38. Conte, P. Biochar, soil fertility, and environment. Biol. Fertil. Soils 2014, 50, 1175. [CrossRef]

39. Morales, V.L.; Pérez-Reche, F.J.; Hapca, S.M.; Hanley, K.L.; Lehmann, J.; Zhang, W. Reverse engineering of biochar. Bioresour. Technol. 2015, 183, 163-174. [CrossRef] [PubMed]

40. Edenborn, S.L.; Edenborn, H.M.; Krynock, R.M.; Zickefoose Haug, K.L. Influence of biochar application methods on the phytostabilization of a hydrophobic soil contaminated with lead and acid tar. J. Environ. Manag. 2015, 150, 226-234. [CrossRef]

41. Inbar, A.; Ben-Hur, M.; Sternberg, M.; Lado, M. Using polyacrylamide to mitigate post-fire soil erosion. Geoderma 2015, 239, 107-114. [CrossRef]

42. Abel, S.; Peters, A.; Trinks, S.; Schonsky, H.; Facklam, M.; Wessolek, G. Impact of Biochar and hydrochar addition on water retention and water repellency of sandy soil. Geoderma 2013, 202, 183-191. [CrossRef] 
43. Herath, H.; Camps-Arbestain, M.; Hedley, M. Effect of biochar on soil physical properties in two contrasting soils: An Alfisol and an Andisol. Geoderma 2013, 209, 188-197. [CrossRef]

44. Laird, D.A.; Fleming, P.; Davis, D.D.; Horton, R.; Wang, B.; Karlen, D.L. Impact of biochar amendments on the quality of a typical Midwestern agricultural soil. Geoderma 2010, 158, 443-449. [CrossRef]

45. Nelissen, V.; Ruysschaert, G.; Manka'Abusi, D.; D’Hose, T.; de Beuf, K.; Al-Barri, B.; Cornelis, W.; Boeckx, P. Impact of a woody biochar on properties of a sandy loam soil and spring barley during a two-year field experiment. Eur. J. Agron. 2015, 62, 65-78. [CrossRef]

46. Omondi, M.O.; Xia, X.; Nahayo, A.; Liu, X.; Korai, P.K.; Pan, G. Quantification of biochar effects on soil hydrological properties using meta-analysis of literature data. Geoderma 2016, 274, 28-34. [CrossRef]

47. Council Directive EC. 31/EC Directive on the landfill of waste, special edition in Polish: Chapter 15. Off. J. 1999, 4, 228-246.

48. GUS-Statistics Poland. Means of production in agriculture in the 2018/19 farming year. Stat. Anal. 2020, 1, 116-185.

49. Weber, J.; Karczewska, A.; Drozd, J.; Licznar, M.; Licznar, S.; Jamroz, E.; Kocowicz, A. Agricultural and ecological aspects of a sandy soil as affected by the application of municipal solid waste composts. Soil Biol. Biochem. 2007, 39, 1294-1302. [CrossRef]

50. Minister of Agriculture and Rural Development. Regulation on the implementation of certain provisions of the Act on fertilizers and fertilization. J. Laws 2008, 765, 6515-6520.

51. IUSS Working Group WRB. World Reference Base for Soil Resources 2014, International Soil Classification System for Naming Soils and Creating Legends for Soil Maps; Update 2015; World Soil Resources Reports No. 106; Food and Agriculture Organization of the United Nations: Rome, Italy, 2015.

52. Polish Society of Soil Science. Particle size distribution and textural classes of soils and mineral materials-Classification of Polish Society of Soil Science 2008. Soil Sci. Ann. 2009, 60, 5-16.

53. Blott, S.J.; Pye, K. Particle size scales and classification of sediment types based on particle size distributions: Review and recommended procedures. Sedimentology 2012, 59, 2071-2096. [CrossRef]

54. Blake, G.R.; Hartge, K.H. Particle density. In Methods of Soil Analysis 1, Physical and Mineralogical Methods; Klute, A., Ed.; ASA-SSSA Inc.: Madison, WI, USA, 1986; pp. 377-382.

55. Blake, G.R.; Hartge, K.H. Bulk density. In Methods of Soil Analysis 1, Physical and Mineralogical Methods; Klute, A., Ed.; ASA-SSSA Inc.: Madison, WI, USA, 1986; pp. 363-375.

56. Danielson, R.E.; Sutherland, P.L. Porosity. In Methods of Soil Analysis 1, Physical and Mineralogical Methods; Klute, A., Ed.; ASA-SSSA Inc.: Madison, WI, USA, 1986; pp. 443-460.

57. Gardner, W.H. Water content. In Methods of Soil Analysis 1, Physical and Mineralogical Methods; Klute, A., Ed.; ASA-SSSA Inc.: Madison, WI, USA, 1986; pp. 493-541.

58. Cassel, D.K.; Nielsen, D.R. Field capacity and available water capacity. In Methods of Soil Analysis 1, Physical and Mineralogical Methods; Klute, A., Ed.; ASA-SSSA Inc.: Madison, WI, USA, 1986; pp. 901-924.

59. Canarache, A.; Vintila, I.; Munteanu, I. Elsevier's Dictionary of Soil Science: Definitions in English with French, German, and Spanish Word Translations; Elsevier BV: Amsterdam, The Netherlands, 2006.

60. Olness, A.; Clapp, C.E.; Liu, R.; Palazzo, A.J. Biosoilds and their effect on soil properties. In Handbook of Soil Conditioners; Wallace, A., Terry, R.E., Eds.; Marcel Dekker: New York, NY, USA, 1998; pp. 141-165.

61. Skopp, J.; Janson, M.D.; Doran, J.W. Steady-State aerobic microbial activity as a function of soil water content. Soil Sci. Soc. Am. J. 1990, 54, 1619-1625. [CrossRef]

62. Mikheeva, I.V. Changes in the probability distributions of particle size fractions in chestnut soil of the Kulunda Steppe under the effect of natural and anthropogenic factors. Eurasian Soil Sci. 2010, 43, 1351-1361. [CrossRef]

63. Carter, M.; Bentley, S.P. Soil Properties and Their Correlations, 2nd ed.; Wiley: Hoboken, NJ, USA, 2016.

64. Githinji, L. Effect of biochar application rate on soil physical and hydraulic properties of a sandy loam. Arch. Agron. Soil Sci. 2014, 60, 457-470. [CrossRef]

65. Ball, B.C.; Campbell, D.J.; Hunter, E.A. Soil compactibility in relation to physical and organic properties at 156 sites in UK. Soil Tillage Res. 2000, 57, 83-91. [CrossRef]

66. Arshad, M.A.; Martin, S. Identifying critical limits for soil quality indicators in agro ecosystems. Agric. Ecosyst. Environ. 2002, 88, 153-160. [CrossRef]

67. Logsdon, S.D.; Karlen, D.L. Bulk density as a soil quality indicator during conversion to no-tillage. Soil Tillage Res. 2004, 78, 143-149. [CrossRef] 
68. Paluszek, J. Criteria of evaluation of physical quality of Polish arable soils. Acta Agrophys. 2011, 191, 1-139.

69. Pranagal, J.; Podstawka-Chmielewska, E.; Słowińska-Jurkiewicz, A. Influence on selected physical properties of a Haplic Podzol during a ten-year fallow period. Pol. J. Environ. Stud. 2007, 16, 875-880.

70. Walczak, R.; Ostrowski, J.; Witkowska-Walczak, B.; Sławiński, C. Hydrophysical characteristics of Polish mineral arable soils. Acta Agrophys. 2002, 79, 1-64.

71. Pranagal, J. The Physical State of Selected Silty Soils of on the Lublin Region. Ph.D. Thesis, University of Life Sciences in Lublin, Lublin, Poland, 2011.

72. Mayers, W.S.; Barrs, H.D. Roots in irrigated clay soil: Measurement techniques and responses to root zone conditions. Irrig. Sci. 1991, 12, 125-134.

73. Cockroft, B.; Olsson, K.A. Case study of soil quality in south-eastern Australia: Management of structure for roots in duplex soils. In Soil Quality for Crop Production and Ecosystem Health; Gregorich, e.g., Carter, M.R., Eds.; Elsevier: Amsterdam, The Netherlands, 1997; pp. 339-350.

74. Reynolds, W.D.; Drury, C.F.; Tan, C.S.; Fox, C.A.; Yang, X.M. Use of indicators and volume-function characteristics to quantify soil physical quality. Geoderma 2009, 152, 252-263. [CrossRef]

75. Castellini, M.; Fornaro, F.; Garofalo, P.; Giglio, L.; Rinaldi, M.; Ventrella, D.; Vitti, C.; Vonell, A.V. Effect of no-tillage and conventional tillage on physical and hydraulic properties of fine textured soils under winter wheat. Water 2019, 11, 1-24. [CrossRef]

76. Drewry, J.J. Natural recovery of soil physical properties from treading damage of pastoral soils in New Zealand and Australia: A review. Agric. Ecosyst. Environ. 2006, 114, 159-169. [CrossRef]

77. Mueller, L.; Kay, B.D.; Been, B.; Hu, C.; Zhang, Y.; Wolff, M.; Eulenstein, F.; Schindler, U. Visual assessment of soil structure: Part II. Implications of tillage, rotation and traffic on sites in Canada, China and Germany. Soil Tillage Res. 2008, 103, 188-196. [CrossRef]

78. Pranagal, J.; Woźniak, A. 30 years of wheat monoculture and reduced tillage and physical condition of Rendzic Phaeozem. Agric. Water Manag. 2021, 243, 106408. [CrossRef]

79. Iversen, B.V.; Schjønning, P.; Poulsen, T.G.; Moldrup, P. In-situ, on-situ and laboratory measurements of soil air permeability: Boundary conditions a measurement scale. Soil Sci. 2001, 166, 97-106. [CrossRef]

80. Shukla, M.K.; Lal, R. Air permeability of soil. In Encyclopedia of Soil Science; Lal, R., Ed.; Taylor and Francis: New York, NY, USA, 2006.

81. Mentges, M.I.; Reichert, J.M.; Rodrigues, M.F.; Awe, G.O.; Mentges, L.R. Capacity and intensity soil aeration properties affected by granulometry, moisture, and structure in no-tillage soils. Geoderma 2016, 263, 47-59. [CrossRef]

82. Kuncoro, P.H.; Koga, K.; Satta, N.; Muto, Y. A study on the effect of compaction on transport properties of soil gas and water I: Relative gas diffusivity, air permeability, and saturated hydraulic conductivity. Soil Tillage Res. 2014, 143, 172-179. [CrossRef]

83. Wang, W.; Li, J.; Su, L.; Wang, Q. Soil air permeability model based on soil physical basic parameters. Nongye Jixie Xuebao/Trans. Chin. Soc. Agric. Mach. 2015, 46, 125-130. [CrossRef]

84. Poulsen, T.G.; Iversen, B.V.; Yamaguchi, T.; Moldrup, P.; Schjønning, P. Spatial and temporal dynamics of air permeability in a construction field. Soil Sci. 2001, 166, 153-162. [CrossRef]

85. White, R.E. Principles and Practice of Soil Science, 4th ed.; Blackwell Publishing: Oxford, UK, 2006.

86. Pandian, K.; Subramaniayan, P.; Gnasekaran, P.; Chitraputhirapillai, S. Effect of biochar amendment on soil physical, chemical and biological properties and groundnut yield in rainfed Alfisol of semi-arid tropics. Arch. Agron. Soil Sci. 2016, 62, 1293-1310. [CrossRef]

87. Kutílek, M. Soil hydraulic properties as related to soil structure. Soil Tillage Res. 2004, 79, 175-184. [CrossRef]

88. Leśny, J. Meteorology and Climatology Research. Acta Agrophys. 2010, 184, 1-263.

89. Petrosyants, M.A.; Kislov, A.V.; Semenov, E.K. Principal concepts in meteorology and climatology. Vestnik Moskovskogo Universiteta $S 5$ Geografiya 2005, 1, 83-91.

90. Usowicz, B.; Usowicz, Ł. Point measurements of soil water content and its spatial distribution in cultivated fields. Acta Agrophys. 2004, 4, 573-588.

91. Amézketa, E. Soil aggregate stability: A review. J. Sustain. Agric. 1999, 14, 82-151. [CrossRef]

92. Bronick, C.J.; Lal, R. Soil structure and management: A review. Geoderma 2005, 124, 3-22. [CrossRef]

93. Staricka, J.A.; Benoit, G.R. Freeze-drying effects on wet and dry soil aggregate stability. Soil Sci. Soc. Am. J. 1995, 59, 218-223. [CrossRef] 
94. Asgarzadeh, H.; Mosaddeghi, M.R.; Dexter, A.R.; Mahboubi, A.A.; Neyshabouri, M.R. Determination of soil available water for plants: Consistency between laboratory and field measurements. Geoderma 2014, 226, 8-20. [CrossRef]

95. Olness, A.; Archer, D. Effect of organic carbon on available water in soil. Soil Sci. 2005, 170, 90-101. [CrossRef]

96. Lu, S.G.; Sun, F.F.; Zong, Y.T. Effect of rice husk biochar and coal fly ash on some physical properties of expansive clayey soil (Vertisol). Catena 2014, 114, 37-44. [CrossRef]

Publisher's Note: MDPI stays neutral with regard to jurisdictional claims in published maps and institutional affiliations.

(C) 2020 by the authors. Licensee MDPI, Basel, Switzerland. This article is an open access article distributed under the terms and conditions of the Creative Commons Attribution (CC BY) license (http://creativecommons.org/licenses/by/4.0/). 